\title{
Instruments to measure patient experience of healthcare quality in hospitals: a systematic review
}

\author{
Michelle Beattie $^{1 *}$, Douglas J. Murphy ${ }^{2}$, lain Atherton ${ }^{3}$ and William Lauder ${ }^{4}$
}

\begin{abstract}
Background: Improving and sustaining the quality of hospital care is an international challenge. Patient experience data can be used to target improvement and research. However, the use of patient experience data has been hindered by confusion over multiple instruments (questionnaires) with unknown psychometric testing and utility.

Methods: We conducted a systematic review and utility critique of questionnaires to measure patient experience of healthcare quality in hospitals. Databases (Medical Literature Analysis and Retrieval System (MEDLINE), Cumulative Index to Nursing and Allied Health Literature (CINAHL), Psychological Information (PsychINFO) and Web of Knowledge until end of November 2013) and grey literature were scrutinised. Inclusion criteria were applied to all records with a $10 \%$ sample independently checked. Critique included (1) application of COSMIN checklists to assess the quality of each psychometric study, (2) critique of psychometric results of each study using Terwee et al. criteria and (3) development and critique of additional aspects of utility for each instrument. Two independent reviewers completed each critique. Synthesis included combining findings in a utility matrix.
\end{abstract}

Results: We obtained 1157 records. Of these, 26 papers measuring patient experience of hospital quality of care were identified examining 11 international instruments. We found evidence of extensive theoretical/development work. The quality of methods and results was variable but mostly of a high standard. Additional aspects of utility found that (1) cost efficiency was mostly poor, due to the resource necessary to obtain reliable samples; (2) acceptability of most instruments was good and (3) educational impact was variable, with evidence on the ease of use, for approximately half of the questionnaires.

Conclusions: Selecting the right patient experience instrument depends on a balanced consideration of aspects of utility, aided by the matrix. Data required for high stakes purposes requires a high degree of reliability and validity, while those used for quality improvement may tolerate lower levels of reliability in favour of other aspects of utility (educational impact, cost and acceptability).

Systematic review registration: PROSPERO CRD42013006754

Keywords: Systematic review, Patient, Experience, Satisfaction, Quality, Hospital, Acute care, Instruments, Questionnaires, Surveys, Utility

\footnotetext{
* Correspondence: michelle.beattie@stir.ac.uk

'School of Health Sciences, Centre for Health Science, University of Stirling,

Highland Campus, Old Perth Rd, Inverness IV2 3JH, UK

Full list of author information is available at the end of the article
} 


\section{Background}

Despite an array of improvement initiatives in hospitals, the quality of care delivered remains open to question $[12,14,18]$. Patients who have experienced hospitalisation can offer unique insights into quality of care, which can be used for improvement. Yet, patients' views of quality of care are not always included in hospital measurement plans [4]. However, if patient experience data is to be used to improve quality of care in hospitals, it needs to be reliable and valid yet usable in practice $[11,54]$.

Measurement is fundamental to improving the quality of hospital care [43]. We will only know whether interventions or changes are working if processes and outcomes are measured. Measuring the patient experience in a robust way enables facts to be established from the complex phenomena of quality of care [32]. Patient experience data can be used to benchmark hospital performance, monitor effectiveness of interventions, establish hospital rankings and secure funding for research and innovation. Quantitative data can be combined with patient stories to create compelling evidence to evoke reflection and improvements within clinical teams [30]. Measuring the patient experience can highlight potential solutions, opportunities to improve hospital care.

Although a combination of tools is required to capture the complexity of hospital care, surveys are likely to remain the core method for measuring patient experience [11]. Surveys or questionnaires can be used to capture large samples of standardised data, which is essential if the patient perspective is to be equally represented alongside other aspects of care easier to quantify, such as waiting times.

There are, however, challenges to measuring the patient perspective of hospital care using questionnaires. Firstly, quality of care is difficult to quantify and define [5]. There is no widely accepted definition of quality of care; rather, there is an understanding that it is multidimensional, with varying interpretations dependent on who is being asked [16]. The widely accepted STEEEP acronym (Safety, Timeliness, Effectiveness, Efficiency, Equity and Person Centeredness) is most commonly used to describe the dimensions of quality of care [23]. There is consensus that quality of care consists of technical (knowledge and expertise) and interpersonal divisions (i.e. empathetic behaviour) [5, 16]. For example, the explanation of treatment options (technical) is improved if they are explained in an empathic and personcentred way (interpersonal).

Secondly, the terms 'satisfaction' and 'experience' are often used interchangeably despite their different meanings. Satisfaction is the gap between patient expectations and experience. Patients tend to overrate satisfaction, due to gratitude bias and other factors. Therefore, the validity and usefulness of satisfaction data is limited; thus, there are calls for the patients' perspective of quality of care to focus on measuring experience, as opposed to satisfaction $[31,57,58]$. Patient experience is defined as things that happen to people and the extent that people's needs are met [17]. Questions are, therefore, designed around what actually occurred during hospitalisation. For example, a question might be asked as to whether or not patients received the right medication, at the right time as opposed to asking patients to rate their satisfaction with medicine administration. The emphasis is on asking patients whether or not, or how often, they have experienced certain care processes, rather than on rating aspects of care or treatment.

Thirdly, instruments need to be valid and reliable. That is, they accurately represent the patient experience of hospital care (validity), and this is measured consistently (reliability). An example of validity would be ensuring the patient experience is being measured, rather than the clinicians' perspective, as these are known to differ [16]. An unreliable tool would not be able to monitor improvement over time, consistently and without error.

Finally, instruments need to have high utility if they are to be used in real-world practice [3]. Van der Vleuten considered instrument utility from five aspects, namely validity, reliability, cost efficiency, acceptability and educational impact [52]. Each of these aspects is important to users of patient experience instruments. In the current financial climate, cost had become a key consideration when selecting an instrument. For example, obtaining a large, standardised sample will be expensive. Acceptability considers the suitability of the instrument from the users' perspective. This includes not only measuring a valid construct but also the tolerability of the instrument. For example, users (patients, clinicians and managers) may think a questionnaire has an unacceptably high number of questions, despite internal consistency (reliability) being improved by increasing the number of items [10]. Educational impact is also a factor to consider. How easy is it for an organisation, or individual within it, to drill down and make use of the data? Van der Vleuten emphasises the importance of weighing all of these aspects to select the right instrument, for the right purpose. For example, if survey results are to be used for high stakes (the outcome has important consequences for an individual or organisation), there is a necessity for high reliability, while tolerating high cost. Data used for team improvement may tolerate lower levels of reliability but require educational impact and acceptability.

This systematic review critiques the utility of published questionnaires aiming to measure the adult inpatient experience of hospital quality of care. The findings will aid appropriate instrument selection, 
which will ultimately increase the likelihood of the patient's voice improving hospital quality of care.

\section{Study objectives}

1. Identify questionnaires available to measure the adult inpatient experience of general (medical/ surgical) hospital quality care.

2. Identify studies conducted to examine the measurement properties (validity and reliability) of questionnaires quantifying the adult inpatient experience of quality care.

3. Identify papers exploring the cost efficiency, acceptability and educational impact of questionnaires measuring the adult inpatient experience of hospital quality care.

4. Critique the quality of the methods and results of the measurement properties using recognised criteria for each instrument.

5. Determine the utility of each questionnaire by integrating results on the quality of validity, reliability, cost efficiency, acceptability and educational impact.

\section{Methods}

Our methods were published in a protocol [4] prior to conducting the review, and this study was registered with PROSPERO (registration number CRD42013006754). A PRISMA (2009) Checklist aided the study design (see Additional file 1).

\section{Search strategy}

Search strategies were devised, and the following databases were searched from inception until end of November 2013 as follows: Medical Literature Analysis and Retrieval System (MEDLINE), Cumulative Index to Nursing and Allied Health Literature (CINAHL) and Psychological Information (PsychINFO). No restrictions were applied to language, publication type or year. The word 'satisfaction' was included in our strategies, as some papers pertaining to 'experience' were filed under satisfaction within Medical Index Subject Headings (MeSH) within databases. Other literature was identified by contacting experts in the field and searching specialist websites (see Additional file 2 for MEDLINE search strategy and resources searched). Some e-mails were not responded to; we set a definitive deadline for response for July 2014. All records were exported into Ref Works for removal of duplicates and reference management. Duplicate removal was second checked within Ref Works and amended by hand by MB.

\section{Selection criteria}

An inclusion selection form was applied to all titles and abstracts, enabling a transparent and focused selection of papers of interest: [4]

Study type: examining any measurement properties, theoretical development or utility of a questionnaire.

Population: adult in-patients, thus excluding clinicians, family members and paediatric perspectives.

Setting: surgical or medical care, thus excluding specialist areas, such as palliative and psychiatric care as patients in specialist areas have different determinants of what constitutes quality of care [38, 44].

Global perspective: patients' overall experience of hospital quality of care. Therefore, we eliminated conditionspecific instruments and those measuring quality of specific professional groups.

Construct of interest: quality of care. We included all definitions or conceptualisations of quality, so long as they were defined from the patients' perspective. Studies measuring patient satisfaction were eliminated due to the theoretical and methodological limitations identified earlier.

Where decisions could not be made on title or abstract alone, full papers were retrieved. A second reviewer independently applied the inclusion criteria to a random $10 \%$ of the records, retrieving full papers where necessary.

\section{Data extraction/instrument overview}

We used a data extraction form to standardise the information recorded and aid analyses [31]. Some instruments have been considered by multiple studies; therefore, papers were grouped according to the instrument type to reduce duplication of data extraction. Data was extracted from the most recent version of the instrument only. All data extracted were checked for accuracy by a second, independent researcher.

\section{Assessment of study quality}

The Consensus-based Standards for the Selection of Health Measurement Instruments (COSMIN) checklist was used to evaluate the methodological rigour of the studies [34, 51], and Quality Criteria for Measurement Properties [50] was used to critique the results of the studies. Studies were not rejected on the basis of this quality critique; rather, the results were synthesised to enable appropriate instrument selection.

The COSMIN checklists have been designed and validated for use in evaluating the rigour of psychometric studies of healthcare instruments [34]. The COSMIN checklist provides separate checklists (referred to as boxes) for each type of measurement property, for example, box A is for internal consistency, B for reliability and so forth. Boxes $\mathrm{A}-\mathrm{H}$ are for different types of 
psychometric studies and have their own associated quality questions. See Mokkink et al [34] for a full explanation of the COSMIN checklist. The checklists for interpretability and generalisability were not used as these are recommended for data extraction use only and are not scored for quality. All quality grading of studies were scored independently by two researchers ( $M B$, DM) before reaching consensus.

There were several steps in the quality critique of retained studies and instruments (Fig. 1 of quality critique procedure). Firstly, we applied the appropriate A-H checklist to critique the methodological quality of how each measurement property was being tested within each study. Responses within individual checklists were given a methodological score by applying the COSMIN four-point checklist scoring system. The scoring system is designed to ensure that items are scored as 'excellent' when there is evidence of adequate methodological quality, 'good' when relevant information is not fully reported but adequate quality can be assumed, 'fair' if the methodological quality is in doubt and 'poor' when there is evidence that the methodological quality is not adequate. Where answers to checklist questions were of variable ratings (i.e. some excellent, some poor), the overall score was determined by taking the lowest rating of any item. In other words, the worst score counted [51].

Secondly, we rated the quality of the results of the psychometric studies by using the Quality Criteria for Measurement Properties devised by Terwee et al. (see Table 1) [50]. Results were rated as positive (+), indeterminate (?) or negative (-) according to the quality criteria for each measurement property. For example, positive ratings for internal consistency are given, using Terwee et al. criteria, if Cronbach's alpha is $\geq 0.70$. Studies with Cronbach's alpha results of $<0.70$ would be categorised as negative, or where Cronbach's alpha was not determined, the result would be categorised as indeterminate. A full explanation, with justification for all COSMIN criteria results, is available from Terwee et al. [50].

\section{Development of quality matrix}

The COSMIN checklists only enable a critique of the validity and reliability aspects of utility; as a third step in devising a quality matrix, we developed additional questions to rate the cost efficiency, acceptability and educational impact of instruments (Table 2). Each question response has a four-point rating criteria of excellent, good, fair or poor.

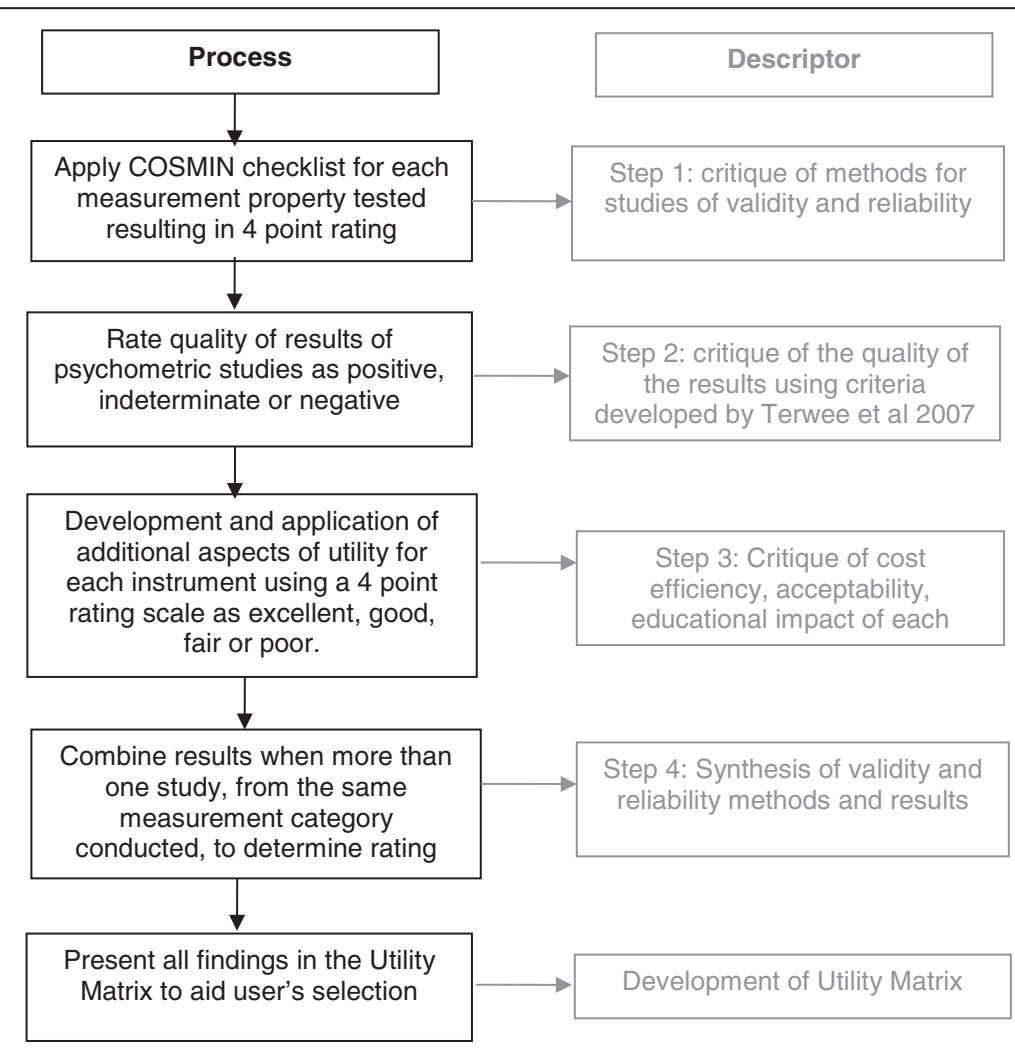

Fig. 1 Quality critique procedure 
Table 1 Quality Criteria for Measurement Properties (Terwee et al. 2007) [50]

\begin{tabular}{|c|c|c|}
\hline Property & Rating & Quality criteria \\
\hline \multicolumn{3}{|l|}{ Reliability } \\
\hline \multirow[t]{3}{*}{ Internal consistency } & $(+)$ & (Sub)scale unidimensional AND Cronbach's alpha(s) $\geq 0.70$ \\
\hline & $?$ & Dimensionality not known OR Cronbach's alpha not determined \\
\hline & $(-)$ & (Sub)scale not unidimensional OR Cronbach's alpha(s) $<0.70$ \\
\hline \multirow[t]{3}{*}{ Measurement error } & $(+)$ & MIC > SDC OR MIC outside the LOA \\
\hline & $?$ & MIC not defined \\
\hline & $(-)$ & MIC $\leq$ SDC OR MIC equals or inside LOA \\
\hline \multirow[t]{3}{*}{ Reliability } & $(+)$ & ICC/weighted Kappa $\geq 0.70$ OR Pearson's $r \geq 0.80$ \\
\hline & $?$ & Neither ICC/weighted Kappa, nor Pearson's $r$ determined \\
\hline & $(-)$ & ICC/weighted Kappa $<0.70$ OR Pearson's $r<0.80$ \\
\hline \multicolumn{3}{|l|}{ Validity } \\
\hline \multirow[t]{3}{*}{ Content validity } & $(+)$ & $\begin{array}{l}\text { The target population considers all items in the questionnaire } \\
\text { to be relevant AND considers the questionnaire to be complete }\end{array}$ \\
\hline & $?$ & No target population involvement \\
\hline & $(-)$ & $\begin{array}{l}\text { The target population considers all items in the questionnaire } \\
\text { to be irrelevant OR considers the questionnaire to be incomplete }\end{array}$ \\
\hline \multicolumn{3}{|l|}{ Construct validity } \\
\hline \multirow[t]{3}{*}{ Structural validity } & $(+)$ & Factors should explain at least $50 \%$ of the variance \\
\hline & $?$ & Explained variance not mentioned \\
\hline & $(-)$ & Factors explain $<50 \%$ of the variance \\
\hline \multirow[t]{3}{*}{ Hypothesis testing } & $(+)$ & $\begin{array}{l}\text { Correlation with an instrument measuring the same construct } \geq 50 \% \\
\text { OR atleast } 75 \% \text { of the results is in accordance with the hypotheses) AND } \\
\text { correlation with related constructs is higher than with unrelated constructs }\end{array}$ \\
\hline & $?$ & Solely correlations determined with unrelated constructs \\
\hline & $(-)$ & $\begin{array}{l}\text { Correlation with an instrument measuring the same construct }<50 \% \text { OR }<75 \% \\
\text { of the results is in accordance with the hypotheses OR correlation with related } \\
\text { constructs is lower than with unrelated constructs }\end{array}$ \\
\hline
\end{tabular}

+ positive, - negative, ? indeterminate, AUC area under the curve, MIC minimal important change, ICC intraclass correlation, SDC smallest detectable change, LOA limits of agreement

Cost efficiency was rated in terms of the resources necessary to utilise the instrument for its primary purpose. The higher the resource/cost required, the lower the rating. Sample sizes detailed in instrument papers were used to answer the first question 'What are the number of observations (patients, raters, times) needed to reach the required level of reliability for the purpose of the instrument?' The number of observations needed to achieve the desired level of reliability is important to establish in terms of feasibility [35]. An instrument may be highly reliable but require extensive resource to obtain a reliable sample. Therefore, we are determining the resources necessary to achieve the level of reliability necessary for the instrument's primary purpose. For example, the Hospital Consumer Assessment of Healthcare Providers and Systems (HCAHPS) instrument requires a minimum of 300 questionnaires per hospital to achieve a minimum of 0.8 reliability for all reported measures [20]. Also, if an instrument requirement was use on two or more occasions to obtain reliability (i.e. test re-test reliability) where time affected the instrument performance, there would be a need to multiply the number of assessments by the given number of administrations.

Another question estimated the resource required to administer the questionnaire, for example, assessments requiring to be conducted by experts are more expensive in comparison to self-completion questionnaires. Completion time was also included; where developers had not published information on completion times, estimates were calculated by comparing with similar instruments. Question 4 brought together the preceding three questions on cost efficiency to estimate the cost of obtaining a reliable sample: minimal, moderate, considerable or extensive. These categories transformed into an inverse rating scale from poor to excellent, 'extensive', for example, becoming a rating of 'poor' for cost efficiency.

For the utility dimension of acceptability, questions were designed around evidence of the subjects' 
Table 2 Additional aspects of utility scoring criteria

\begin{tabular}{|c|c|c|c|c|}
\hline & Excellent $(* * * *)$ & Good $(* * *)$ & Fair $\left(^{* *}\right)$ & Poor $(*)$ \\
\hline \multicolumn{5}{|l|}{ Questions for cost efficiency } \\
\hline $\begin{array}{l}\text { 1. What are the number of } \\
\text { observations (patients, raters, } \\
\text { times) needed to reach the } \\
\text { required level of reliability for } \\
\text { the purpose of the instrument? }\end{array}$ & $\begin{array}{l}\text { Only a small sample } \\
\text { needed }(<30)\end{array}$ & $\begin{array}{l}\text { A moderate sample } \\
\text { size (30-49) }\end{array}$ & $\begin{array}{l}\text { Not explicit but can be } \\
\text { assumed or (50-99 } \\
\text { assessments needed) }\end{array}$ & $\begin{array}{l}\text { No details given or ( } \geq 100 \\
\text { assessments needed) }\end{array}$ \\
\hline $\begin{array}{l}\text { 2. How long does an assessment } \\
\text { take to complete }\end{array}$ & $\leq 15 \min$ & $\leq 30 \min$ & $30-60 \mathrm{~min}$ & $>60 \mathrm{~min}$ \\
\hline $\begin{array}{l}\text { 3. What are the administrative } \\
\text { costs of completing the } \\
\text { assessment? }\end{array}$ & $\begin{array}{l}\text { Easily embedded } \\
\text { within existing } \\
\text { resource. Little } \\
\text { additional support } \\
\text { required }\end{array}$ & $\begin{array}{l}\text { Some administrative } \\
\text { resource but no } \\
\text { specialist resource } \\
\text { required }\end{array}$ & $\begin{array}{l}\text { Large amount of resource } \\
\text { required to assess and } \\
\text { administer }\end{array}$ & $\begin{array}{l}\text { Significant specialist expertise } \\
\text { and administrative time } \\
\text { required to assess and } \\
\text { administer }\end{array}$ \\
\hline $\begin{array}{l}\text { 4. What is the cost to complete a } \\
\text { reliable sample? }\end{array}$ & Minimal & Moderate & Considerable & Extensive \\
\hline \multicolumn{5}{|l|}{ Questions for acceptability } \\
\hline $\begin{array}{l}\text { 1. Is there evidence of subjects } \\
\text { understanding of the } \\
\text { instrument/assessment? }\end{array}$ & $\begin{array}{l}\text { Investigations of } \\
\text { subjects } \\
\text { understanding (i.e. } \\
\text { cognitive testing of } \\
\text { instruments) }\end{array}$ & $\begin{array}{l}\text { Estimated evidence of } \\
\text { subjects understanding } \\
\text { (i.e. high number of } \\
\text { questions missed) }\end{array}$ & $\begin{array}{l}\text { Subject understanding not } \\
\text { explicitly stated but some } \\
\text { can be assumed (i.e. } \\
\text { student guide to OSCE) }\end{array}$ & $\begin{array}{l}\text { No evidence of subject } \\
\text { understanding }\end{array}$ \\
\hline $\begin{array}{l}\text { 2. How many assessments are not } \\
\text { completed? }\end{array}$ & $\begin{array}{l}\text { There are low } \\
\text { numbers of missing } \\
\text { items }(<10 \%) \text { and } \\
\text { adequate response } \\
\text { rates }(\geq 40 \%)\end{array}$ & $\begin{array}{l}\text { There are a high } \\
\text { number of missing } \\
\text { items }(\geq 10 \%) \text { and an } \\
\text { adequate response } \\
\text { rates }(\geq 40 \%)\end{array}$ & $\begin{array}{l}\text { There are low numbers of } \\
\text { missing items or poor } \\
(<10 \%) \text { and an inadequate } \\
\text { response rate }(<40 \%)\end{array}$ & $\begin{array}{l}\text { There are high numbers of } \\
\text { missing items }(\geq 10 \%) \text { and } \\
\text { poor response rates }(<40 \%)\end{array}$ \\
\hline $\begin{array}{l}\text { 3. Has the instrument/assessment } \\
\text { been tested in an appropriate } \\
\text { context? }\end{array}$ & $\begin{array}{l}\text { Evidence of } \\
\text { successful } \\
\text { administration/use } \\
\text { within an appropriate } \\
\text { setting }\end{array}$ & $\begin{array}{l}\text { Tested in vivo and } \\
\text { changes } \\
\text { recommended would } \\
\text { be achievable }\end{array}$ & $\begin{array}{l}\text { Testing in vivo and } \\
\text { changes recommended } \\
\text { would be difficult or only } \\
\text { partially tested in vivo }\end{array}$ & $\begin{array}{l}\text { Testing has only been } \\
\text { conducted in vitro/simulation }\end{array}$ \\
\hline \multicolumn{5}{|l|}{ Questions for educational impact } \\
\hline $\begin{array}{l}\text { 1. There is evidence of the } \\
\text { instruments intended purpose } \\
\text { being achieved (i.e. if aim is to } \\
\text { enable hospital ranking for } \\
\text { patient selection, is there } \\
\text { evidence that the results are } \\
\text { actually influencing patient } \\
\text { choice?) }\end{array}$ & $\begin{array}{l}\text { Clear evidence of } \\
\text { intended purpose } \\
\text { being fulfilled }\end{array}$ & $\begin{array}{l}\text { Explanatory or } \\
\text { theoretical link } \\
\text { between intended and } \\
\text { actual use but no clear } \\
\text { evidence }\end{array}$ & $\begin{array}{l}\text { Evidence of theoretical } \\
\text { work but relationship } \\
\text { between intended and } \\
\text { actual purpose poorly or } \\
\text { not described }\end{array}$ & $\begin{array}{l}\text { No evidence of intended } \\
\text { purpose becoming actual }\end{array}$ \\
\hline $\begin{array}{l}\text { 2. The scoring system is easily } \\
\text { translated or available in an easy } \\
\text { to use format? }\end{array}$ & $\begin{array}{l}\text { Explicitly stated and } \\
\text { easy to calculate }\end{array}$ & $\begin{array}{l}\text { Explicitly stated but } \\
\text { not easy to calculate }\end{array}$ & $\begin{array}{l}\text { Scoring only calculated by } \\
\text { resource with statistical } \\
\text { knowledge }\end{array}$ & $\begin{array}{l}\text { Scoring not explained well } \\
\text { enough to calculate }\end{array}$ \\
\hline $\begin{array}{l}\text { 3. The feedback from the results } \\
\text { can be readily used for action } \\
\text { where necessary? }\end{array}$ & $\begin{array}{l}\text { Feedback is readily } \\
\text { available in a format } \\
\text { that enables } \\
\text { necessary action }\end{array}$ & $\begin{array}{l}\text { Feedback is readily } \\
\text { available but not } \\
\text { drilled down enough } \\
\text { to enable targeted } \\
\text { action }\end{array}$ & $\begin{array}{l}\text { Minimal feedback available } \\
\text { or delay results in limited } \\
\text { impact }\end{array}$ & $\begin{array}{l}\text { No explanation to determine } \\
\text { adequacy of feedback. No } \\
\text { direct feedback could be } \\
\text { readily used without additional } \\
\text { expertise }\end{array}$ \\
\hline
\end{tabular}

perception of the instrument, where less acceptance would result in a lower rating. There is an overlap between this category and content validity. However, the COSMIN checklist for content validity does not cover all aspects of user acceptability, e.g. cognitive testing. Also, some instruments may demonstrate content validity but have only been tested in a simulated environment or have an unacceptably high number of questions. Grading was determined on a four-point rating scale of excellent, good, fair and poor. The overall rating of acceptability was determined by the worst score.

Questions for educational impact required evidence around an instrument's ease of use for learning or decisionmaking. Using a validated and reliable instrument is futile if not followed by action, learning or impact. This category 
determines how easy it is to make use of the instrument results as intended. Again, question responses were graded using four rating responses, with the final rating determined by the worst score.

Where responses within individual categories of utility dimensions differed, the overall score was determined by the worst score counts, except for cost efficiency, where scoring was based on a balance of responses. Questions and categorised responses were refined following the testing of application to one instrument. Two researchers independently scored all papers and resolved disagreements through consensus.

\section{Beattie and Murphy instrument utility matrix}

All results were integrated into a utility matrix to aid instrument selection for users. The matrix enabled a synthesis of the quality of the methods used in the studies and results of all measurement properties from each study of each instrument, from the application of COSMIN and Terwee et al. criteria [50]. To simplify, the results from validity studies were merged into three headings: content, construct and criterion validity. Content validity included any study on the theoretical development of the instrument construction. Studies empirically testing any other type of validity, except criterion, were grouped together as construct validity. Construct validity is an overarching term for validity as opposed to a distinct form [10]. However, criterion validity was retained as a separate category as this is viewed as the 'gold standard', indicating the ability of an instrument to predict future outcomes, which would be of interest to those selecting an instrument.

Reliability was presented in the matrix in two categories: internal consistency and other forms of reliability. Internal consistency is the relationship between items and accounts for error generated by the questions or items asked by the instrument [49]. Measurement of internal consistency is only relevant when instruments have been designed from a reflective model. To determine whether instruments derived from a reflective model, we asked the question 'Do we expect all items to change when the construct changes?' If changes to the patient experience of quality of care did not result in changes in all domains, we classified the questionnaire as derived from a formative model. Also, measures of internal consistency are based on a single administration of the instrument and essentially represent the average of correlations among all the items in the instrument [49]. However, this does not account for the potential error between different observers or from one time interval to another. Generalizability G-theory and its associated decision D-studies can be used to further explore the reliability of an instrument and research the most effective blend of relevant resources (times of administration, number of observers or raters) needed to explain error and attain reliability [20,49]. To address the potential for misinterpreting an instrument as reliable when demonstrating high internal consistency but where other sources of error had not been examined, we added a question to the matrix to indicate whether or not all relevant sources of errors were investigated.

We presented ratings of study quality in star ratings: excellent $(* * * *)$, good $(* * *)$, fair $(* *)$ and poor $*$ and the quality of results as positive (+), (?). Where more than one study from the same measurement category had been conducted, we determined the average point to rate the quality of the study methods. We provide two examples of combining validity and reliability scores to further explain. Example 1: if structural validity scored 'excellent' and cross-cultural validity scored 'fair', our overall rating would be 'good'. If, however, structural validity scored 'excellent' and cross-cultural validity scored 'good', we would rate validity overall as good to excellent (represented as $* * * * * * * * *)$. Example 2: if the same instrument had two studies on reliability with study quality for one scoring 'excellent' and the other scoring 'good', we would rate reliability overall as good to excellent (represented as $* * * * * * * * *)$. Where the quality of study results varied, within the same measurement property, we presented these as mixed. For example, if structural validity results scored positive and cross-cultural validity scored negative, we presented these as mixed (+/-).

\section{Results}

Results of the search strategy were documented within the PRISMA flow diagram (see Fig. 2) [33]. We obtained 1157 records from our searches. Following removal of duplicates, 1000 records were screened for inclusion criteria. Application of the inclusion criteria to titles and abstracts resulted in the exclusion of 890 records. We retrieved 110 full-text articles where we were unable to make decisions from the title and abstract. Following application of inclusion criteria to full-text articles, we rejected 84 and retained 26 papers.

\section{Screening results}

A second reviewer applied the inclusion criteria to a random $10 \%$ of the 1000 papers $(n=100)$. Where the second reviewer was unable to make a decision on title and abstract alone, full-text papers were retrieved $(n=17)$. We rejected numerous papers where the outcome of interest, or theoretical model, was patient satisfaction, as opposed to patient experience (see Fig. 2 for specific exclusion results). The percentage of agreement between both reviewers was $90 \%$, therefore demonstrating a highly reliable process. Reviewers reached consensus following discussion on the remaining ten 


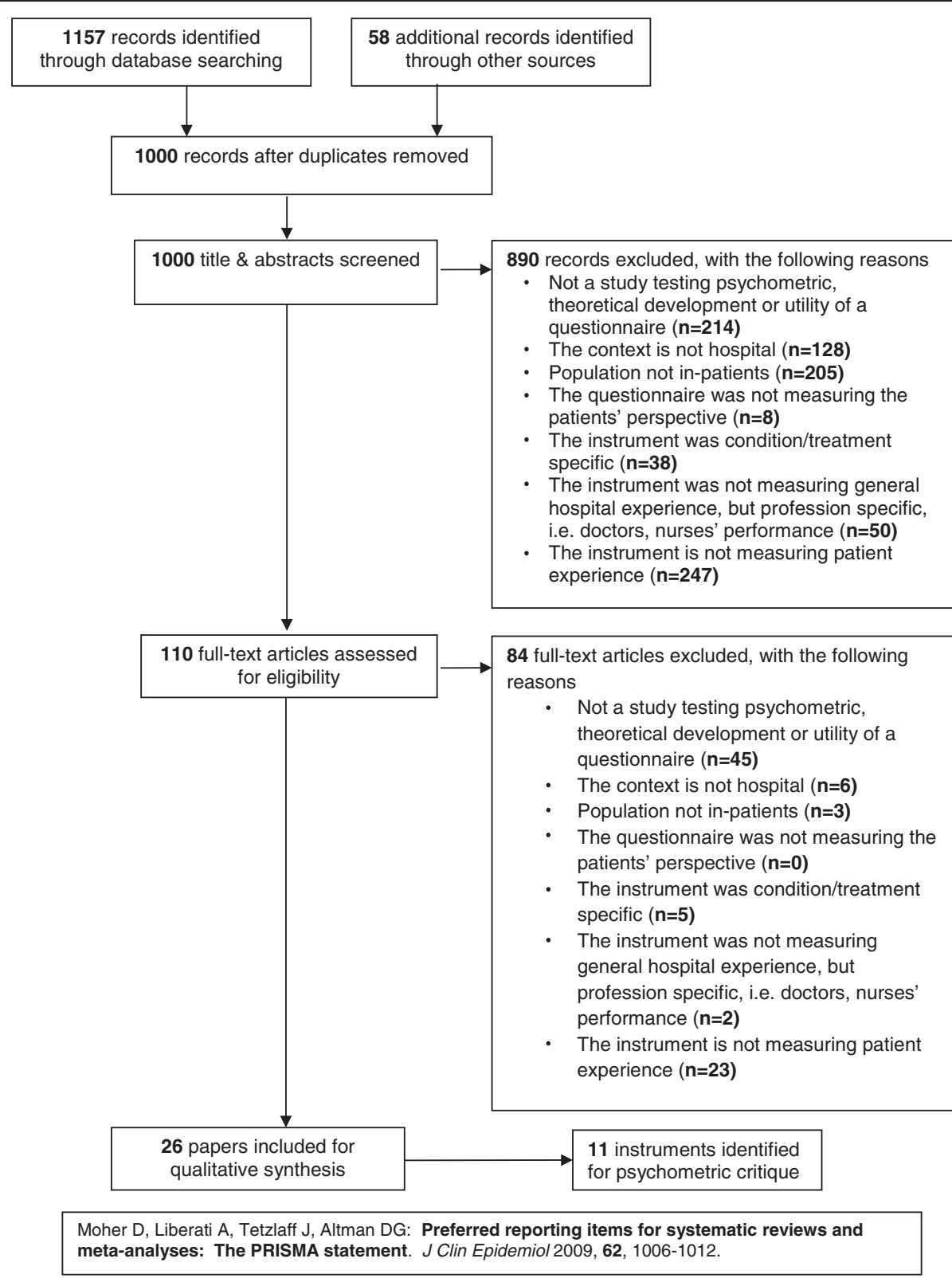

Fig. 2 Modified PRISMA flow diagram

papers. The process resulted in 26 papers being retained in relation to 11 instruments measuring the patient experience of hospital quality of care.

\section{Characteristics of included instruments}

The range of instruments and associated papers can be found in Table 3. Instruments were available across the World: Ethiopia (1), Hong Kong (1), India (1), Scandinavia (4), UK (3) and USA (1). Most instruments had generated multiple versions as they developed over time; therefore, we critiqued the most recent instrument version and associated psychometric studies published in November 2013. For example, we used the Scottish Inpatient Patient Experience Survey (SIPES) measure version 2012 [46] as there is approximately a 1-year time lag between the instrument's use and results. Some instruments had extensive developmental histories, for example, the $\mathrm{Na}$ tional Health Service Inpatient (NHSIP) Survey has been operating annually since 2002 [40], but its theoretical development work can be traced back to as early as 1991, to the original Picker Adult In-Patient survey [2, 9, 19]. We included the most recent works only. The Hospital 
Table $\mathbf{3}$ Instrument overview

\begin{tabular}{|c|c|c|c|c|c|c|c|}
\hline Instrument/abbreviation & $\begin{array}{l}\text { Associated } \\
\text { papers }\end{array}$ & $\begin{array}{l}\text { Country of } \\
\text { origin }\end{array}$ & Domains covered & $\begin{array}{l}\text { Conceptual } \\
\text { framework }\end{array}$ & $\begin{array}{l}\text { No. } \\
\text { of } \\
\text { items }\end{array}$ & Mode of administration & $\begin{array}{l}\text { Timing of } \\
\text { administration }\end{array}$ \\
\hline \multirow{7}{*}{$\begin{array}{l}\text { Hospital Consumer } \\
\text { Assessment of Healthcare } \\
\text { Providers and Systems } \\
\text { (HCAHPS) }\end{array}$} & $\begin{array}{l}\text { Sofaer et al. } \\
\text { [48] }\end{array}$ & \multirow[t]{7}{*}{ USA } & Nurse communication & \multirow[t]{7}{*}{ Reflective } & \multirow[t]{7}{*}{24} & Mail & \multirow[t]{7}{*}{$\begin{array}{l}48 \mathrm{~h}-6 \text { weeks } \\
\text { of discharge }\end{array}$} \\
\hline & Keller et al. [26] & & $\begin{array}{l}\text { Doctor } \\
\text { communication }\end{array}$ & & & Telephone & \\
\hline & O'Malley [36] & & Physical comfort & & & \multirow{3}{*}{$\begin{array}{l}\text { Mail with telephone } \\
\text { follow-up }\end{array}$} & \\
\hline & $\begin{array}{l}\text { Levine et al. } \\
\text { [29] }\end{array}$ & & Pain control & & & & \\
\hline & $\begin{array}{l}\text { Giordano et al. } \\
{[20]}\end{array}$ & & $\begin{array}{l}\text { Medicine } \\
\text { communication }\end{array}$ & & & & \\
\hline & $\begin{array}{l}\text { Agency for } \\
\text { Healthcare } \\
\text { Research and } \\
\text { Quality [1] }\end{array}$ & & Discharge information & & & \multirow[t]{2}{*}{$\begin{array}{l}\text { Interactive Voice } \\
\text { Recognition (IVR) }\end{array}$} & \\
\hline & $\begin{array}{l}\text { Centers for } \\
\text { Medicare and } \\
\text { Medicaid [8] }\end{array}$ & & $\begin{array}{l}\text { Responsiveness to } \\
\text { patient }\end{array}$ & & & & \\
\hline \multirow[t]{10}{*}{$\begin{array}{l}\text { Quality from the Patients' } \\
\text { Perspective (QPP) }\end{array}$} & $\begin{array}{l}\text { Wilde et al. } \\
\text { [56] }\end{array}$ & \multirow[t]{10}{*}{ Sweden } & $\begin{array}{l}\text { Medical-technical } \\
\text { competence }\end{array}$ & \multirow[t]{10}{*}{ Reflective } & \multirow[t]{10}{*}{68} & \multirow[t]{10}{*}{$\begin{array}{l}\text { Self-completion } \\
\text { questionnaire }\end{array}$} & \multirow[t]{10}{*}{ At discharge } \\
\hline & $\begin{array}{l}\text { Wilde et al. } \\
\text { [55] }\end{array}$ & & $\begin{array}{l}\text { Physical technical } \\
\text { conditions }\end{array}$ & & & & \\
\hline & \multirow{8}{*}{$\begin{array}{l}\text { Larsson et al. } \\
\text { [28] }\end{array}$} & & Personal necessities & & & & \\
\hline & & & Characteristics & & & & \\
\hline & & & $\begin{array}{l}\text { Identity-orientated } \\
\text { approach }\end{array}$ & & & & \\
\hline & & & Situation & & & & \\
\hline & & & Participation & & & & \\
\hline & & & Commitment & & & & \\
\hline & & & $\begin{array}{l}\text { Socio-cultural } \\
\text { atmosphere }\end{array}$ & & & & \\
\hline & & & $\begin{array}{l}\text { Positive treatment of } \\
\text { significant others }\end{array}$ & & & & \\
\hline \multirow{4}{*}{$\begin{array}{l}\text { Quality from the Patients' } \\
\text { Perspective Shortened } \\
\text { (QPPS) }\end{array}$} & \multirow[t]{4}{*}{$\begin{array}{l}\text { Larsson et al. } \\
{[27]}\end{array}$} & \multirow[t]{4}{*}{ Sweden } & $\begin{array}{l}\text { Medical-technical } \\
\text { competence }\end{array}$ & \multirow[t]{4}{*}{ Reflective } & \multirow[t]{4}{*}{24} & \multirow[t]{4}{*}{$\begin{array}{l}\text { Self-completion } \\
\text { questionnaire }\end{array}$} & \multirow[t]{4}{*}{ At discharge } \\
\hline & & & $\begin{array}{l}\text { Physical technical } \\
\text { conditions }\end{array}$ & & & & \\
\hline & & & $\begin{array}{l}\text { Identity-orientated } \\
\text { approach }\end{array}$ & & & & \\
\hline & & & $\begin{array}{l}\text { Socio-cultural } \\
\text { atmosphere }\end{array}$ & & & & \\
\hline \multirow[t]{7}{*}{$\begin{array}{l}\text { Picker Patient Experience } \\
\text { Questionnaire (PPE-15) }\end{array}$} & $\begin{array}{l}\text { Jenkinson et al. } \\
\text { [25] }\end{array}$ & \multirow[t]{7}{*}{ England } & $\begin{array}{l}\text { Information and } \\
\text { education }\end{array}$ & \multirow[t]{7}{*}{ Reflective } & \multirow[t]{7}{*}{15} & \multirow[t]{7}{*}{$\begin{array}{l}\text { Self-completion postal } \\
\text { questionnaire }\end{array}$} & \multirow[t]{7}{*}{$\begin{array}{l}\text { Within } 1 \text { month } \\
\text { of discharge }\end{array}$} \\
\hline & $\begin{array}{l}\text { Jenkinson et al. } \\
\text { [24] }\end{array}$ & & Coordination of care & & & & \\
\hline & \multirow{5}{*}{$\begin{array}{l}\text { Reeves et al. } \\
\text { [42] }\end{array}$} & & Physical comfort & & & & \\
\hline & & & Emotional support & & & & \\
\hline & & & $\begin{array}{l}\text { Respect for patient } \\
\text { preferences }\end{array}$ & & & & \\
\hline & & & $\begin{array}{l}\text { Involvement of family } \\
\text { and friends }\end{array}$ & & & & \\
\hline & & & $\begin{array}{l}\text { Continuity and } \\
\text { transition }\end{array}$ & & & & \\
\hline
\end{tabular}


Table 3 Instrument overview (Continued)

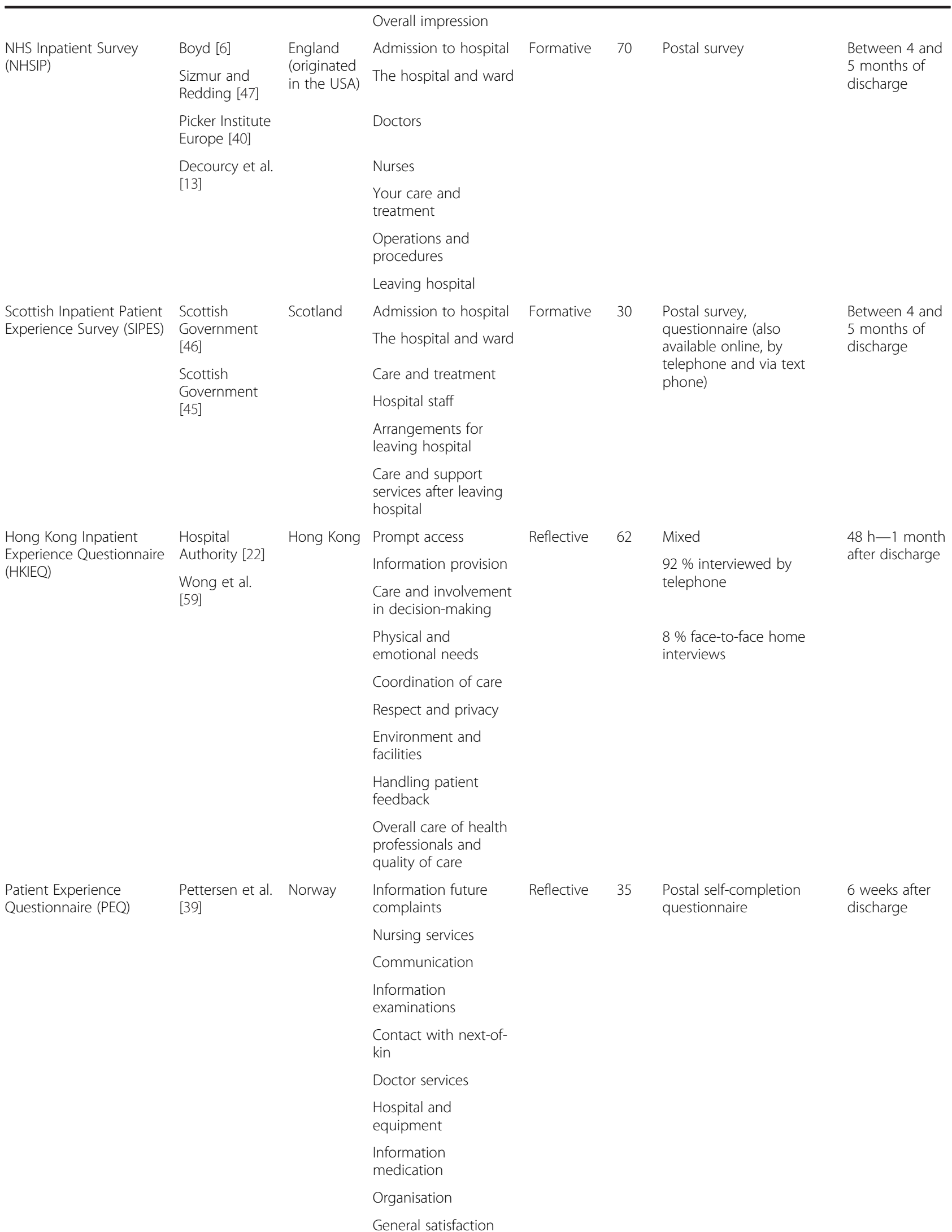


Table 3 Instrument overview (Continued)

\begin{tabular}{|c|c|c|c|c|c|c|c|}
\hline \multirow{6}{*}{$\begin{array}{l}\text { Norwegian Patient } \\
\text { Experience Questionnaire } \\
\text { (NORPEQ) }\end{array}$} & \multirow[t]{6}{*}{ Oltedal [37] } & \multirow[t]{6}{*}{ Norway } & $\begin{array}{l}\text { Whether doctors were } \\
\text { understandable }\end{array}$ & \multirow[t]{6}{*}{ Reflective } & \multirow[t]{6}{*}{8} & \multirow[t]{6}{*}{ Self-completion } & \multirow[t]{6}{*}{$\begin{array}{l}\text { Within } 7 \text { weeks } \\
\text { of discharge }\end{array}$} \\
\hline & & & $\begin{array}{l}\text { Doctors professional } \\
\text { skills }\end{array}$ & & & & \\
\hline & & & $\begin{array}{l}\text { Nurses professional } \\
\text { skills }\end{array}$ & & & & \\
\hline & & & Nursing care & & & & \\
\hline & & & $\begin{array}{l}\text { Whether doctors and } \\
\text { nurses were interested } \\
\text { in the patients } \\
\text { problems }\end{array}$ & & & & \\
\hline & & & Information on tests & & & & \\
\hline \multirow{5}{*}{$\begin{array}{l}\text { Patient Experiences with } \\
\text { Inpatient Care (I-PAHC) }\end{array}$} & \multirow{5}{*}{$\begin{array}{l}\text { Webster et al. } \\
\text { [53] }\end{array}$} & \multirow[t]{5}{*}{ Ethiopia } & Nurse communication & \multirow[t]{5}{*}{ Reflective } & \multirow[t]{5}{*}{16} & \multirow{5}{*}{$\begin{array}{l}\text { Interviewer-assisted } \\
\text { completion }\end{array}$} & \multirow{5}{*}{$\begin{array}{l}\text { After first day of } \\
\text { admission }\end{array}$} \\
\hline & & & $\begin{array}{l}\text { Doctor } \\
\text { communication }\end{array}$ & & & & \\
\hline & & & Physical environment & & & & \\
\hline & & & Pain management & & & & \\
\hline & & & $\begin{array}{l}\text { Medication and } \\
\text { symptom } \\
\text { communication }\end{array}$ & & & & \\
\hline \multirow{5}{*}{$\begin{array}{l}\text { Patient Perceptions of } \\
\text { Quality (PPQ) }\end{array}$} & \multirow[t]{5}{*}{ Rao et al. [41] } & \multirow[t]{5}{*}{ India } & Medicine availability & \multirow[t]{5}{*}{ Reflective } & \multirow[t]{5}{*}{16} & \multirow{5}{*}{$\begin{array}{l}\text { Interviewer-assisted } \\
\text { completion }\end{array}$} & \multirow[t]{5}{*}{ Not specified } \\
\hline & & & Medical information & & & & \\
\hline & & & Staff behaviour & & & & \\
\hline & & & Doctor behaviour & & & & \\
\hline & & & Hospital infrastructure & & & & \\
\hline
\end{tabular}

Consumer Assessment of Healthcare Providers and Systems (HCAHPS) originated in 2002 [1], but we used version 2012 [2].

Instruments covered similar domains to capture the patient experience of their hospital care. Some focused on stages of the patient's journey, from admission to hospital discharge $[6,46]$. Others were structured around dimensions of hospital quality, i.e. communication and coordination of care, such as HCAHPS [2] and Quality from the Patients' Perspective Shortened (QPPS) [56]. All instruments covered aspects of technical and interpersonal components of quality of care. There were some cultural differences in content. For example, the Patient Perceptions of Quality (PPQ) [41] included questions around medicine availability, reflective of the low-income context in which the instrument was tested. Importantly, all instruments were measuring the patient experience, as opposed to satisfaction.

Most instruments were devised from a reflective model (see Table 3). That is to say, collectively, factors within the questionnaire reflect the construct of interest, patient experience of hospital quality. For example, changes made to improve the quality of hospital care (construct) would likely cause variation in all indicators, i.e. safety and person centeredness within these instruments. The NHSIP and SIPES instruments were exceptions, based on a formative model. Domains within their questionnaire were designed around the patient journey, i.e. from admission to discharge home. A poor experience during admission to hospital (indicator) would decrease the patient's score of quality of care, but not necessarily influence other indicators, i.e. the patient's experience of hospital discharge.

The number of items within the instruments varied from 8 to 70, excluding demographic questions. All instruments were self-completed instruments, except Patient Experiences with Inpatient Care (I-PAHC) and PPQ which required interviewer assistance due to the prevalence of illiteracy in the countries in which they were tested $[41,53]$. Most instruments were mailed, although some offered telephone assistance (HCAHPS, SIPES, NHSIP) and HCAHPS was available in several formats (mail only, telephone only, mail followed by telephone and interactive voice response) [8].

All instruments were administered following discharge from hospital, except I-PAHC which was completed any time during the admission, but after the first day of hospitalisation [53]. Timings varied, from instruments being distributed on discharge to several months following hospitalisation. 


\section{Instrument quality and results}

The type and quality of the methods and results of the psychometric studies was variable but mostly of a high standard (see Table 4). Every instrument had evidence of examining at least one aspect of validity and reliability.

\section{Validity}

Content validity was tested for all instruments by exploring which aspects of hospital quality care mattered most to patients. Scores for content validity were rated as good or excellent, except for HCAHPS [48]. HCAHPS was rated as poor as no information was provided to determine whether aspects of quality suggested by patients had been integrated within their instrument, as well as patients having concurred with pre-determined items. While the quality of the methodology and results was limited for HCAHPS, in all other instruments, the questionnaire items were relevant and sufficient, therefore rating positive for content validity.

All instruments had examined other types of validity, except NHSIP and SIPES. Comments in NHSIP documentation referred to previous structural validity, but the detail required to judge criteria was unavailable [47]. Criterion validity is considered when an instrument is compared with a gold standard. While no gold standard exists for measures of patient experience, the COSMIN criteria include comparisons of shortened with original longer versions as criterion validity. Three studies comparing shortened versions with their original longer versions (QPP [55], QPPS [27], PPE-15 [24, 25]), rated fair, excellent and good, respectively, with positive results. Some developers had tested the validity of their instrument extensively, namely QPP, HKIEQ and NORPEQ which had conducted three or more validity studies. The methodological quality of all construct validity studies was mostly good or excellent (HCAHPS), except HKIEQ. [22] HKIEQ was rated as fair as no description was given on how the authors handled missing items within their study. Most results of construct validity were categorised as positive, as factor analysis explained at least $50 \%$ of the variance or met other Quality Criteria for Measurement Properties identified by Terwee et al. (see Table 1) [50]. Several studies were rated as indeterminate as they did not meet the Quality Criteria for Measurement Properties' results. For example, structural validity was thoroughly examined for the HCAHPS instrument but was categorised as indeterminate as structural equation modelling does not report factor loadings [26]. This result needs to be interpreted with caution as the HCAHPS study demonstrated an excellent fit for structural validity. The methodological quality of criterion validity for the QPP instrument was rated as poor as there were flaws identified in the study design [55]. The validity of one QPP study [55] was in doubt as student nurses were given scenarios to act as simulated patients to answer questionnaire items in the instrument.

\section{Reliability}

All instruments studied internal consistency to determine the interrelatedness among items. All instruments achieved positive internal consistency results, except NHSIP [47] which was indiscriminate as Cronbach's alpha was not determined. Importantly, two instruments [45, 47]. were derived from formative models and did not have unidimensional subscales, which is reflected in their indiscriminate results and lower quality findings $[25,47]$. However, the quality of the study methods for five instruments (NHSIP [47], SIPES [45], HKIEQ [22, 59], PEQ [39] and NORPEQ [37]) did not clarify how missing items were handled. Four instruments examined types of reliability in addition to internal consistency (HCAHPS [26], HKIEQ [22], PEQ [39] and NORPEQ [37]). All had positive results, but one HCAHPS study was indeterminate as the minimal important change was not determined as per the Quality Criteria for Measurement Properties (as detailed in Table 1).

\section{Results of instrument utility}

The cost efficiency was rated as good for QPPS [27], NORPEQ [37] and I-PAHC [53]. All other instruments were rated as poor or fair, highlighting that considerable or extensive resource would be required to obtain an adequate sample (see Table 5). All instruments, except QPP, were rated excellent or good for the dimension of acceptability, as there was evidence of user acceptability in an appropriate context. QPP was rated as fair due to the evidence of testing in a simulated setting only [56].

Educational impact was good for five of the instruments (HCAHPS [26, 29, 48], SIPES [45, 46], NORPEQ [37], I-PAHC [37], PPQ [53]) as there was evidence of the instruments being easily used for their intended purpose, i.e. hospital ranking or quality improvement. Five instruments (QPP [55], QPPS [27], PPE-15 [25], NHSIP $[13,40]$, HKIEQ [22]) were rated as fair as there was some evidence of educational impact, and PEQ was rated as poor as there was no enough information to determine educational impact.

\section{Utility matrix results}

All results (critique of methods, results and additional aspects of utility) were embedded in our utility matrix to enable an easy overview and aid instrument selection (see Table 6). We found two main purposes of patient experience instrument use to compare performance across hospitals and local quality improvement. Overall, 
Table 4 Quality of methods and results of psychometric studies

\begin{tabular}{|c|c|c|c|c|c|}
\hline Instrument/abbreviation & $\begin{array}{l}\text { Associated } \\
\text { papers }\end{array}$ & $\begin{array}{l}\text { Measurement } \\
\text { property }\end{array}$ & Result & $\begin{array}{l}\text { Quality rating } \\
\text { of results }\end{array}$ & $\begin{array}{l}\text { Quality } \\
\text { rating of } \\
\text { methods }\end{array}$ \\
\hline \multirow{8}{*}{$\begin{array}{l}\text { Hospital Consumer } \\
\text { Assessment of Healthcare } \\
\text { Providers and Systems } \\
\text { (HCAHPS) }\end{array}$} & $\begin{array}{l}\text { Sofaer et al. } \\
{[48]}\end{array}$ & $\begin{array}{l}\text { Content } \\
\text { validity }\end{array}$ & $\begin{array}{l}\text { Patients considered other aspects of hospital } \\
\text { care which appear to have not been included }\end{array}$ & Negative & Poor \\
\hline & $\begin{array}{l}\text { Keller et al. } \\
{[26]}\end{array}$ & $\begin{array}{l}\text { Internal } \\
\text { consistency }\end{array}$ & Cronbach's alpha 0.70 & Positive & Excellent \\
\hline & $\begin{array}{l}\text { Keller et al. } \\
{[26]}\end{array}$ & Reliability & ICC 0.70 & Positive & Excellent \\
\hline & $\begin{array}{l}\text { Keller et al. } \\
{[26]}\end{array}$ & $\begin{array}{l}\text { Structural } \\
\text { validity }\end{array}$ & $\begin{array}{l}7 \text { categorises for } 16 \text { items. Factor loadings } \\
0.57-91 \text {. Uniqueness of error reported }\end{array}$ & Indeterminate & Excellent \\
\hline & \multirow[t]{4}{*}{ O'Malley [36] } & \multirow[t]{4}{*}{$\begin{array}{l}\text { Measurement } \\
\text { error }\end{array}$} & $\begin{array}{l}\text { Correlation between same composites } \\
\text { different services }\end{array}$ & \multirow[t]{4}{*}{ Indeterminate } & \multirow[t]{4}{*}{ Good } \\
\hline & & & Surgery 0.76 & & \\
\hline & & & Obstetrics 0.73 & & \\
\hline & & & Medical 0.85 & & \\
\hline \multirow[t]{10}{*}{$\begin{array}{l}\text { Quality from the Patients' } \\
\text { Perspective (QPP) }\end{array}$} & $\begin{array}{l}\text { Wilde et al. } \\
\text { [56] }\end{array}$ & $\begin{array}{l}\text { Content } \\
\text { validity }\end{array}$ & $\begin{array}{l}35 \text { patient interviews - development of } \\
\text { relevant questionnaire }\end{array}$ & Positive & Excellent \\
\hline & $\begin{array}{l}\text { Wilde et al. } \\
\text { [55] }\end{array}$ & $\begin{array}{l}\text { Internal } \\
\text { consistency }\end{array}$ & Cronbach's alpha 0.80 & Positive & Excellent \\
\hline & $\begin{array}{l}\text { Wilde et al. } \\
\text { [55] }\end{array}$ & $\begin{array}{l}\text { Content } \\
\text { validity }\end{array}$ & $\begin{array}{l}\text { High patient ratings of item clarity and } \\
\text { comprehensiveness }\end{array}$ & Positive & Excellent \\
\hline & \multirow{5}{*}{$\begin{array}{l}\text { Wilde et al. } \\
\text { [55] }\end{array}$} & \multirow{5}{*}{$\begin{array}{l}\text { Structural } \\
\text { validity }\end{array}$} & Factor solutions & \multirow[t]{5}{*}{ Positive } & \multirow[t]{5}{*}{ Good } \\
\hline & & & Medical/technical competence $50.4 \%$ & & \\
\hline & & & Physical/technical conditions $44.8 \%$ & & \\
\hline & & & Identity-orientated approach $66.9 \%$ & & \\
\hline & & & Socio-cultural atmosphere $65.8 \%$ & & \\
\hline & $\begin{array}{l}\text { Wilde et al. } \\
\text { [55] }\end{array}$ & $\begin{array}{l}\text { Criterion } \\
\text { validity }\end{array}$ & $\begin{array}{l}\text { Correlation between long and short version } \\
\text { in their entirety was } 0.90\end{array}$ & Positive & Poor \\
\hline & $\begin{array}{l}\text { Larsson et al. } \\
{[28]}\end{array}$ & $\begin{array}{l}\text { Structural } \\
\text { validity }\end{array}$ & $\begin{array}{l}\text { RMSEA of } 0.050 \text { was obtained indicating } \\
\text { the model was an acceptable fit }\end{array}$ & Indeterminate & Good \\
\hline \multirow[t]{2}{*}{$\begin{array}{l}\text { Quality from the Patients' } \\
\text { Perspective Shortened (QPPS) }\end{array}$} & $\begin{array}{l}\text { Larsson et al. } \\
\text { [27] }\end{array}$ & $\begin{array}{l}\text { Internal } \\
\text { consistency }\end{array}$ & Cronbach's alpha 0.74 for overall scale & Positive & Excellent \\
\hline & $\begin{array}{l}\text { Larsson et al. } \\
{[27]}\end{array}$ & $\begin{array}{l}\text { Criterion } \\
\text { validity }\end{array}$ & $\begin{array}{l}\text { Pearson correlation coefficients all results } \\
\text { statistically significant } 0.0025 \text { when Bonferroni } \\
\text { corrections made }\end{array}$ & Positive & Excellent \\
\hline \multirow[t]{6}{*}{$\begin{array}{l}\text { Picker Patient Experience } \\
\text { Questionnaire(PPE-15) }\end{array}$} & $\begin{array}{l}\text { Jenkinson } \\
\text { et al. [25] }\end{array}$ & $\begin{array}{l}\text { Internal } \\
\text { consistency }\end{array}$ & Cronbach's alpha 0.8 & Positive & Good \\
\hline & \multirow{2}{*}{$\begin{array}{l}\text { Jenkinson } \\
\text { et al. [24] }\end{array}$} & \multirow{2}{*}{$\begin{array}{l}\text { Internal } \\
\text { consistency }\end{array}$} & 0.89 for 4 pages & \multirow[t]{2}{*}{ Positive } & \multirow[t]{2}{*}{ Excellent } \\
\hline & & & 0.87 for 12 pages & & \\
\hline & $\begin{array}{l}\text { Reeves et al. } \\
\text { [42] }\end{array}$ & $\begin{array}{l}\text { Content } \\
\text { validity }\end{array}$ & $\begin{array}{l}\text { Focus groups, cognitive testing, amendments- } \\
\text { research did not identify any missing items from } \\
\text { patients' perspective }\end{array}$ & Positive & Excellent \\
\hline & $\begin{array}{l}\text { Jenkinson } \\
\text { et al. [25] }\end{array}$ & $\begin{array}{l}\text { Criterion } \\
\text { validity }\end{array}$ & $\begin{array}{l}\text { Correlations between short and long version } \\
\text { between } 0.93(P<0.001) \text { and } 0.95(P<0.001)\end{array}$ & Positive & Good \\
\hline & $\begin{array}{l}\text { Jenkinson } \\
\text { et al. [24] }\end{array}$ & $\begin{array}{l}\text { Hypothesis } \\
\text { testing }\end{array}$ & $\begin{array}{l}\text { Item correlations were above recommended levels } \\
\text { for all PPE items in both survey versions }(0.37-0.61)\end{array}$ & Positive & Excellent \\
\hline \multirow[t]{3}{*}{ NHS Inpatient Survey (NHSIP) } & Boyd [6] & $\begin{array}{l}\text { Content } \\
\text { validity }\end{array}$ & Tested and modified with group of inpatients & Positive & Excellent \\
\hline & $\begin{array}{l}\text { Sizmur and } \\
\text { Redding [47] }\end{array}$ & $\begin{array}{l}\text { Internal } \\
\text { consistency }\end{array}$ & $\begin{array}{l}\text { Item correlations given but Cronbach's alpha not } \\
\text { reported }\end{array}$ & Indeterminate & Fair \\
\hline & & & & Positive & Excellent \\
\hline
\end{tabular}


Table 4 Quality of methods and results of psychometric studies (Continued)

Scottish Inpatient Patient Experience Survey (SIPES)

Hong Kong Inpatien Experience Questionnaire (HKIEQ)

Patient Experience

Hong Kong Inpatient
Experience Questionnaire
(HKIEQ)
Questionnaire (PEQ)

$\begin{array}{ll}\text { Scottish } & \text { Content } \\ \text { Government } & \text { validity }\end{array}$

$$
\text { [45] }
$$

$\begin{array}{ll}\text { Scottish } & \text { Internal } \\ \text { Government } & \text { consistency } \\ \text { [45] } & \end{array}$

Hospital Internal

Authority consistency

[22]

Norwegian Patient Experience Questionnaire (NORPEQ)

Patient Experiences with Inpatient Care (I-PAHC) consistency

\section{Webster} et al. [53]

Webster

et al. [53]
Hospital

[22]

Hospital

Authority

[22]

Hospital

Authority

[22]

Wong et al.

[59]

Wong et al.

[59]

Hospital

Authority

[22]

Pettersen
et al. [39]

Pettersen

et al. [39]

Pettersen

et al. [39]

Pettersen

et al. [39]

Pettersen

et al. [39]

Reliability

Content

validity

Structural

validity

Internal

consistency

Structural validity

Cross-cultural Translated but not cross-culturally validated validity

Internal consistency

Cronbach's alpha greater than 0.70 for overal scale

Reliability

Test re-test 0.62-0.85 with ICC exceeding 0.7

Content

validity

Structural

validity

Oltedal [37]

Oltedal [37]

Oltedal [37]

Hypothesis

testing

Internal consistency

Oltedal [37]

Reliability

Content

validity

Oltedal [37]

Structural

Construct validity

Intraclass correlation $0.42-0.96$ and test re-test 0.78

Participants found the questionnaire

to be clear, understandable, and appropriate

17 factors explained $74 \%$ of the variance

Cronbach's alpha 0.75 for overall scale

18 factors explained $75.5 \%$ of the variance

Grouped more than $600 \mathrm{~m}$ written comment Only mean differences computed

6 items explained $57.7 \%$ variance

Hypothesised scales scores would correlate and held focus groups with previous inpatients

to ensure relevant and sufficient items were covered

20 items, 6 factors accounted for $67 \%$ total variance

Associations between rating scale and external measures, i.e. gender, age, fulfilment of expectations.

Item correlation 0.59-0.71 and Cronbach's alpha 0.85

Intraclass correlation $0.45-0.79$ and test re-test 0.88

Patient interviews found questions and scaling easy to understand and all relevant questions covered $0.6-0.8$ with satisfaction (correlation significant, range from high to low)

Scale scores would correlate $0.4-0.6$ perceptions of incorrect treatment (moderate result)

Scores would correlate $0.1-0.3$ with patient health and physical health. (Result 0.19-0.27)

Cronbach's alpha $>0.78$

Content validity
Positive

Excellent

\begin{tabular}{|c|c|}
\hline Positive & Poor \\
\hline Positive & Fair \\
\hline Positive & Fair \\
\hline Positive & Excellent \\
\hline Positive & Fair \\
\hline Positive & Fair \\
\hline Positive & Fair \\
\hline Indeterminate & Fair \\
\hline Positive & Fair \\
\hline Positive & Fair \\
\hline Positive & Good \\
\hline Positive & Excellent \\
\hline Indeterminate & Poor \\
\hline Positive & Fair \\
\hline Positive & Good \\
\hline Positive & Good \\
\hline Positive & Good \\
\hline Positive & Good \\
\hline
\end{tabular}

Positive Excellent
Focus groups, revisions by stakeholders, translated, cognitively tested and patient groups reported clear questions covering all aspects important to them 
Table 4 Quality of methods and results of psychometric studies (Continued)

\begin{tabular}{|c|c|c|c|c|c|}
\hline & $\begin{array}{l}\text { Webster } \\
\text { et al. [53] }\end{array}$ & $\begin{array}{l}\text { Structural } \\
\text { validity }\end{array}$ & $\begin{array}{l}\text { Kept if item loadings greater than } 0.40 \text {. Variance not } \\
\text { reported }\end{array}$ & Indeterminate & Excellent \\
\hline & $\begin{array}{l}\text { Webster } \\
\text { et al. [53] }\end{array}$ & $\begin{array}{l}\text { Construct } \\
\text { validity }\end{array}$ & $\begin{array}{l}5 \text { factors with loadings } 0.48-0.86 \text {. Results in accordance } \\
\text { with priori hypothesis }\end{array}$ & Positive & Excellent \\
\hline & $\begin{array}{l}\text { Webster } \\
\text { et al. [53] }\end{array}$ & $\begin{array}{l}\text { Cross-cultural } \\
\text { validity }\end{array}$ & Translation done but not empirically tested & Indeterminate & Fair \\
\hline \multirow[t]{3}{*}{$\begin{array}{l}\text { Patient Perceptions of Quality } \\
\text { (PPQ) }\end{array}$} & $\begin{array}{l}\text { Rao et al. } \\
{[41]}\end{array}$ & $\begin{array}{l}\text { Internal } \\
\text { consistency }\end{array}$ & Cronbach's alpha $>0.70$ & Positive & Excellent \\
\hline & $\begin{array}{l}\text { Rao et al. } \\
\text { [41] }\end{array}$ & $\begin{array}{l}\text { Content } \\
\text { validity }\end{array}$ & $\begin{array}{l}\text { Questionnaire devised from qualitative } \\
\text { interviews with patients }\end{array}$ & Positive & Excellent \\
\hline & $\begin{array}{l}\text { Rao et al. } \\
{[41]}\end{array}$ & $\begin{array}{l}\text { Structural } \\
\text { validity }\end{array}$ & 5 dimensions explained $73 \%$ variance & Positive & Excellent \\
\hline
\end{tabular}

HCAHPS, NORPEQ, PPE-15 and I-PAHC demonstrated the most evidence that their instruments were valid and reliable. NHSIP and SIPES demonstrated the least evidence of validity and reliability. All other instruments were found to have a degree of psychometric evidence. The most cost-effective instruments were QPPS, NORPEQ and I-PAHC. All instruments demonstrated good or excellent acceptability, except QPP. Several instruments (HCAHPS, SIPES, NORPEQ, I-PAHC and PPQ) were rated as good for educational impact.

\section{Discussion}

To our knowledge, this is the first systematic review to identify and critique the utility of instruments aiming to measure patient experience of hospital quality. We found 11 international instruments measuring the patient experience of hospital care, while we dismissed numerous measuring patient satisfactions. We critiqued utility from a wide perspective, using international standards where they were available and devising additional criteria where needed.

Reassuringly, all instruments reported some psychometric testing and published information on other aspects of utility. Similar literature reviews have found that studies do not report sufficient psychometric information to enable critique, although this has improved over the last 10 years $[7,21]$. We found enough reported psychometric information to critique the retained instruments, although some missing data may have resulted in studies being apportioned lower scores for study quality.

Of course, validity and reliability are not 'all or nothing' concepts; rather, they are a matter of degree. Evidence of validity tends to be cumulative, as each new study provides further confirmation of the ability of an instrument to measure patient experience of hospital quality care. As validation develops over time, it is important not to dismiss newer instruments with only some validation. The reliability of an instrument is also strengthened over time as developers refine the tool and identify ways in which to reduce the margin of error, such as the establishment of a training manual and, of course, developments in psychometrics.

While the longevity of instruments is an identified strength, there should also be a note of caution. Wellestablished instruments may rely on historical data to establish theories and concepts of quality of hospital care. What constitutes Quality from the Patients' Perspective is likely to shift over time [4]; therefore, we suggest that elements of hospital care which are important to patients are re-explored at least every few years, to re-ensure continued instrument validity. We also found evidence of items being added to instruments to fit the current healthcare policy context $[6,46]$. While this seems reasonable, there is a risk that an instrument becomes a measure of healthcare policy implementation as opposed to measuring the patient experience of the quality of hospital care. Conducting interviews or surveys to assess the impact of additional items addressing policy aims should also ensure that such changes do not alter the overall validity of questionnaire content from the patient's perspective. We found extensive work in terms of theoretical and conceptual development of instruments in this area, which is necessary for an elusive and evolving concept of quality of health care.

We found no studies assessing the ability of an instrument to detect change over time in the construct to be measured, otherwise known as responsiveness [15]. This was surprising given that one of the main uses of patient experience instruments is to measure hospital care quality for evaluation of local improvement work. This review highlights both the need for and the current gap in studies assessing responsiveness of these instruments.

This systematic review highlights that there is no 'onesize-fits-all' approach in selecting an instrument to measure the patient experience of hospital quality of care. Rather, there are a range of instruments available with varying strengths and limitations of instrument utility. Instrument choice will, therefore, be dependent upon a number of factors, specifically the purpose for 
Table 5 Results of additional aspects of utility

\begin{tabular}{|c|c|c|c|c|c|c|c|c|c|c|}
\hline & \multicolumn{2}{|l|}{ HCAHPS } & \multicolumn{2}{|l|}{ QPP } & \multicolumn{2}{|l|}{ QPPS } & \multicolumn{2}{|l|}{ PPE-15 } & \multicolumn{2}{|l|}{ NHSIP } \\
\hline & $\mathrm{F}$ & $\mathrm{R}$ & $\mathrm{F}$ & $\mathrm{R}$ & $\mathrm{F}$ & $\mathrm{R}$ & $\mathrm{F}$ & $\mathrm{R}$ & $\mathrm{F}$ & $\mathrm{R}$ \\
\hline \multicolumn{11}{|l|}{ Cost efficiency } \\
\hline $\begin{array}{l}\text { 1. What are the number of observations } \\
\text { (patients, raters, times) needed to reach } \\
\text { the required level of reliability for the } \\
\text { purpose of the instrument? }\end{array}$ & $\geq 300[20]$ & Poor & Not reported & Poor & Not reported & Poor & 330 per group [24] & Poor & Not Reported & Poor \\
\hline $\begin{array}{l}\text { 2. How long does an assessment take to } \\
\text { complete? }\end{array}$ & $8 \min [8]$ & Good & $30 \min [28]$ & Good & $\leq 15 \min$ & Excellent & $12 \min [42]$ & Excellent & 20 min (estimate) & Good \\
\hline $\begin{array}{l}\text { 3. What are the administrative costs of } \\
\text { completing the assessment? }\end{array}$ & $\begin{array}{l}V \text { large } \\
\text { numbers and } \\
\text { expertise [8] }\end{array}$ & Poor & Considerable [28] & Fair & $\begin{array}{l}\text { Brief and easy } \\
\text { scoring [27] }\end{array}$ & Excellent & $\begin{array}{l}\text { Large no. and } \\
\text { standardised data }\end{array}$ & Fair & $\begin{array}{l}\text { Large no. and } \\
\text { standardised }\end{array}$ & Fair \\
\hline $\begin{array}{l}\text { 4. What is the cost to complete a reliable } \\
\text { sample? }\end{array}$ & Extensive & Poor & Considerable & Fair & Minimal & Good & Considerable & Fair & Extensive & Poor \\
\hline Overall Rating & POOR & & FAIR & & GOOD & & FAIR & & POOR & \\
\hline \multicolumn{11}{|l|}{ Acceptability } \\
\hline $\begin{array}{l}\text { 1. Is there evidence of subjects } \\
\text { understanding of the instrument/ } \\
\text { assessment? }\end{array}$ & Yes $[29,48]$ & Excellent & Yes [55] & Excellent & Yes [8] & Excellent & Yes [42] & Excellent & Yes [47] & Excellent \\
\hline $\begin{array}{l}\text { 2. How many assessments are not } \\
\text { completed? }\end{array}$ & $\begin{array}{l}25 \% \text { miss RR } \\
47 \%\end{array}$ & Good & $\begin{array}{l}13 \% \text { miss RR } 68 \% \\
{[55]}\end{array}$ & Good & $\begin{array}{l}25 \% \text { miss RR } 79 \% \\
{[55]}\end{array}$ & Good & $\begin{array}{l}29 \% \text { miss RR } 68 \% \\
{[42]}\end{array}$ & Good & $\begin{array}{l}\text { No info RR } 49 \% \\
{[47]}\end{array}$ & Good \\
\hline $\begin{array}{l}\text { 3. Has the instrument/assessment } \\
\text { been tested in an appropriate context? }\end{array}$ & Yes [26] & Excellent & $\begin{array}{l}\text { Tested in } \\
\text { simulation [55] }\end{array}$ & Fair & Yes [55] & Good & Yes [42] & Excellent & Yes [47] & Excellent \\
\hline Overall Rating & Good & & Fair & & Good & & Good & & Good & \\
\hline \multicolumn{11}{|l|}{ Educational impact } \\
\hline $\begin{array}{l}\text { 1. Is there evidence of the instrument } \\
\text { being used for its intended purpose? } \\
\text { (i.e. if aim is to provide hospital } \\
\text { ranking for patient selection, is there } \\
\text { evidence that the results } \\
\text { are influencing patient choice?) }\end{array}$ & $\begin{array}{l}\text { Evidence of } \\
\text { purpose }[20]\end{array}$ & Excellent & $\begin{array}{l}\text { Discussion of } \\
\text { purpose but no } \\
\text { evidence [55] }\end{array}$ & Fair & $\begin{array}{l}\text { Discussion of } \\
\text { purpose but no } \\
\text { evidence [27] }\end{array}$ & Fair & $\begin{array}{l}\text { Explanatory use for } \\
\text { national } \\
\text { comparison }\end{array}$ & Good & $\begin{array}{l}\text { Clear evidence of } \\
\text { purpose [47] }\end{array}$ & Excellent \\
\hline $\begin{array}{l}\text { 2. Is the scoring system easily translated } \\
\text { or available in an easy to use format? }\end{array}$ & Easy scoring & Excellent & Easy scoring & Excellent & Easy scoring & Excellent & Easily scored & Excellent & $\begin{array}{l}\text { Statistical } \\
\text { knowledge }\end{array}$ & Fair \\
\hline $\begin{array}{l}\text { 3. Can the results be readily used for action } \\
\text { where necessary? }\end{array}$ & $\begin{array}{l}\text { Available but } \\
\text { not at unit/ } \\
\text { team level }\end{array}$ & Good & $\begin{array}{l}\text { Results actionable } \\
\text { at local level }\end{array}$ & Excellent & $\begin{array}{l}\text { Results actionable } \\
\text { at local level }\end{array}$ & Excellent & $\begin{array}{l}\text { Adjustments } \\
\text { needed (Jenkinson } \\
\text { comparison) }\end{array}$ & Fair & $\begin{array}{l}\text { Expertise required } \\
\text { to enable local } \\
\text { action }\end{array}$ & Fair \\
\hline Overall Rating & Good & & Fair & & Fair & & Fair & & Fair & \\
\hline
\end{tabular}


Table 5 Results of additional aspects of utility (Continued)

\begin{tabular}{|c|c|c|c|c|c|c|c|c|c|c|c|c|}
\hline & \multicolumn{2}{|l|}{ SIPE } & \multicolumn{2}{|l|}{ HKIEQ } & \multicolumn{2}{|l|}{ PEQ } & \multicolumn{2}{|l|}{ NORPEQ } & \multicolumn{2}{|l|}{ I-PAHC } & \multicolumn{2}{|l|}{$\mathrm{PPQ}$} \\
\hline & $\mathrm{F}$ & R & $\mathrm{F}$ & R & F & R & $\mathrm{F}$ & $\mathrm{R}$ & $\mathrm{F}$ & $\mathrm{R}$ & $\mathrm{F}$ & R \\
\hline \multicolumn{13}{|l|}{ Cost efficiency } \\
\hline $\begin{array}{l}\text { 1. What are the number of observations } \\
\text { (patients, raters, times) needed to reach } \\
\text { the required level of reliability for the } \\
\text { purpose of the instrument? }\end{array}$ & $\begin{array}{l}\text { Variable but } \\
>100\end{array}$ & Poor & $300-500$ [45] & Poor & $\begin{array}{l}\text { Not } \\
\text { specified }\end{array}$ & Poor & $\begin{array}{l}\text { Not } \\
\text { specified }\end{array}$ & Poor & $\geq 230[53]$ & Poor & $\begin{array}{l}\text { Not } \\
\text { specified }\end{array}$ & Poor \\
\hline $\begin{array}{l}\text { 2. How long does an assessment take to } \\
\text { complete? }\end{array}$ & $20 \min [46]$ & Good & $25 \min [59]$ & Good & $\begin{array}{l}<30 \text { min } \\
\text { (estimate) }\end{array}$ & Good & $\begin{array}{l}>15 \text { min } \\
\text { (estimate) }\end{array}$ & Excellent & $15 \min [53]$ & Excellent & $\begin{array}{l}<30 \text { min } \\
\text { (estimate) }\end{array}$ & Good \\
\hline $\begin{array}{l}\text { 3. What are the administrative costs of } \\
\text { completing the assessment? }\end{array}$ & $\begin{array}{l}V \text { large } \\
\text { numbers and } \\
\text { expertise }\end{array}$ & Poor & $\begin{array}{l}V \text { large } \\
\text { numbers and } \\
\text { expertise }\end{array}$ & Poor & Considerable & Fair & $\begin{array}{l}\text { Brief and } \\
\text { simple } \\
\text { scoring }\end{array}$ & Good & $\begin{array}{l}\text { Interviewers } \\
\text { required }\end{array}$ & Fair & $\begin{array}{l}\text { Interviewer } \\
\text { required [41] }\end{array}$ & Fair \\
\hline $\begin{array}{l}\text { 4. What is the cost to complete a reliable } \\
\text { sample? }\end{array}$ & Extensive & Poor & Extensive & Poor & Considerable & Fair & Moderate & Good & Moderate & Good & Considerable & Fair \\
\hline Overall Rating & POOR & & POOR & & FAIR & & GOOD & & GOOD & & FAIR & \\
\hline \multicolumn{13}{|l|}{ Acceptability } \\
\hline $\begin{array}{l}\text { 1. Is there evidence of subjects } \\
\text { understanding of the instrument/ } \\
\text { assessment? }\end{array}$ & Yes [45] & Excellent & Yes [22] & Excellent & Yes [39] & Excellent & Yes [37] & Excellent & Yes [53] & Excellent & Yes [41] & Excellent \\
\hline $\begin{array}{l}\text { 2. How many assessments are not } \\
\text { completed? }\end{array}$ & $\begin{array}{l}\text { No info RR } \\
50 \%[13]\end{array}$ & Good & $\begin{array}{l}21 \% \text { miss RR } \\
49 \%[22]\end{array}$ & Good & $\begin{array}{l}>10 \% \text { mis } \\
\text { RR } 53 \%[39]\end{array}$ & Excellent & $\begin{array}{l}42.5 \% \text { mis } \\
\text { RR } 48 \% \\
{[37] 85 \%}\end{array}$ & Excellent & $\begin{array}{l}\text { High No RR } \\
95 \%[53]\end{array}$ & Good & $\begin{array}{l}0 \% \text { miss RR } \\
85 \%[41]\end{array}$ & Excellent \\
\hline $\begin{array}{l}\text { 3. Has the instrument/assessment } \\
\text { been tested in an appropriate context? }\end{array}$ & Yes [45] & Excellent & Yes [22] & Excellent & Yes [39] & Excellent & Yes & Excellent & Yes & Excellent & Yes & Excellent \\
\hline Overall Rating & Good & & Good & & Excellent & & Excellent & & Good & & Excellent & \\
\hline \multicolumn{13}{|l|}{ Educational impact } \\
\hline $\begin{array}{l}\text { 1. Is there evidence of the instrument } \\
\text { being used for its intended purpose? } \\
\text { (i.e. if aim is to provide hospital } \\
\text { ranking for patient selection, is there } \\
\text { evidence that the results } \\
\text { are influencing patient choice?) }\end{array}$ & $\begin{array}{l}\text { Explanatory } \\
\text { use for } \\
\text { national } \\
\text { comparison } \\
{[45]}\end{array}$ & Good & $\begin{array}{l}\text { Explanatory use } \\
\text { for national } \\
\text { benchmarking } \\
{[22]}\end{array}$ & Good & $\begin{array}{l}\text { Clear } \\
\text { evidence of } \\
\text { purpose [39] }\end{array}$ & Excellent & $\begin{array}{l}\text { Explanatory } \\
\text { use } \\
\text { described } \\
{[37]}\end{array}$ & Good & $\begin{array}{l}\text { Explanatory } \\
\text { use } \\
\text { described } \\
\text { [53] }\end{array}$ & Good & $\begin{array}{l}\text { Explanatory } \\
\text { use } \\
\text { described } \\
{[41]}\end{array}$ & Good \\
\hline $\begin{array}{l}\text { 2. Is the scoring system easily translated } \\
\text { or available in an easy to use format? }\end{array}$ & $\begin{array}{l}\text { Easy colour } \\
\text { coding }\end{array}$ & Excellent & $\begin{array}{l}\text { Statistical } \\
\text { expertise }\end{array}$ & Fair & $\begin{array}{l}\text { Not } \\
\text { explained }\end{array}$ & Poor & Easy scoring & Excellent & Easy scoring & Excellent & Easy scoring & Excellent \\
\hline $\begin{array}{l}\text { 3. Can the results be readily used for action } \\
\text { where necessary? }\end{array}$ & $\begin{array}{l}\text { Results at } \\
\text { hospital level }\end{array}$ & Good & $\begin{array}{l}\text { Results at } \\
\text { hospital level }\end{array}$ & Good & $\begin{array}{l}\text { No } \\
\text { information }\end{array}$ & Poor & $\begin{array}{l}\text { Readily } \\
\text { available }\end{array}$ & Excellent & $\begin{array}{l}\text { Readily } \\
\text { available }\end{array}$ & Excellent & $\begin{array}{l}\text { Readily } \\
\text { available }\end{array}$ & Excellent \\
\hline Overall Rating & Good & & Fair & & Poor & & Good & & Good & & Good & \\
\hline
\end{tabular}


Table 6 Results of Beattie and Murphy instrument utility matrix

\begin{tabular}{|c|c|c|c|c|c|c|c|c|c|c|}
\hline \multirow[t]{2}{*}{ Instrument } & \multirow{2}{*}{$\begin{array}{l}\text { Primary } \\
\text { purpose }\end{array}$} & \multicolumn{3}{|l|}{ Validity } & \multicolumn{3}{|l|}{ Reliability } & \multirow{2}{*}{$\begin{array}{l}\text { Cost } \\
\text { efficiency } \\
\text { Rating }\end{array}$} & \multirow{2}{*}{$\begin{array}{l}\text { Acceptability } \\
\text { Rating }\end{array}$} & \multirow{2}{*}{$\begin{array}{l}\text { Educational } \\
\text { impact } \\
\text { Rating }\end{array}$} \\
\hline & & $\begin{array}{l}\text { Content/ } \\
\text { theoretical } \\
\text { development }\end{array}$ & $\begin{array}{l}\text { Construct } \\
\text { (structural, } \\
\text { cross- } \\
\text { cultural) }\end{array}$ & $\begin{array}{l}\text { Criterion } \\
\text { validity }\end{array}$ & $\begin{array}{l}\text { Internal } \\
\text { consistency }\end{array}$ & $\begin{array}{l}\text { Other } \\
\text { reliability }\end{array}$ & $\begin{array}{l}\text { Was the } \\
\text { correct error } \\
\text { source } \\
\text { investigated? }\end{array}$ & & & \\
\hline HCAHPS & $\begin{array}{l}\text { National } \\
\text { comparisons }\end{array}$ & $*(-)$ & $* * * *(?)$ & & $* * * *(+)$ & $* * * / * * * *\left(\begin{array}{l}+ \\
?\end{array}\right)$ & $Y$ & * & $* * *$ & $* * *$ \\
\hline QPP & $\begin{array}{l}\text { Quality } \\
\text { improvement }\end{array}$ & $* * * *(+)$ & $* * *(+)$ & $*(+)$ & $* * * *(+)$ & & Y & $* *$ & $* *$ & $* *$ \\
\hline QPPS & $\begin{array}{l}\text { Quality } \\
\text { improvement }\end{array}$ & & & $* * * *(+)$ & $* * * *(+)$ & & P & $* * *$ & $* * *$ & $* *$ \\
\hline PPE-15 & $\begin{array}{l}\text { National } \\
\text { performance } \\
\text { indicators }\end{array}$ & $* * * *(+)$ & $* * * *(+)$ & $* * *(+)$ & $* * * / * * * *(+)$ & & $P$ & $* *$ & $* * *$ & $* *$ \\
\hline NHSIP & $\begin{array}{l}\text { National } \\
\text { performance } \\
\text { indicators }\end{array}$ & $* * * *(+)$ & & & $* *(?)$ & & $N$ & * & $* * *$ & $* *$ \\
\hline SIPES & $\begin{array}{l}\text { National } \\
\text { comparisons }\end{array}$ & $* * * *(+)$ & & & $*(+)$ & & $N$ & * & $* * * *$ & $* * *$ \\
\hline HKIEQ & $\begin{array}{l}\text { National } \\
\text { comparisons }\end{array}$ & $* * * *(+)$ & $* *\left(\begin{array}{l}+ \\
?\end{array}\right)$ & & $* *(+)$ & $* *(+)$ & Y & * & $* * *$ & $* *$ \\
\hline PEQ & $\begin{array}{l}\text { Quality } \\
\text { improvement } \\
\text { and national } \\
\text { surveillance }\end{array}$ & $* * *(+)$ & $* * / * * *\left(\begin{array}{l}+ \\
?\end{array}\right)$ & & $* *(+)$ & $* *(+)$ & Y & $* *$ & $* * * *$ & $*$ \\
\hline NORPEQ & $\begin{array}{l}\text { Cross-national } \\
\text { comparisons in } \\
\text { Nordic } \\
\text { countries }\end{array}$ & ${ }^{* * *}(+)$ & $* * *(+)$ & & $* *(+)$ & $* * *(+)$ & Y & $* * *$ & $* * * *$ & $* * *$ \\
\hline I-PAHC & $\begin{array}{l}\text { Quality } \\
\text { improvement } \\
\text { in low-income } \\
\text { settings }\end{array}$ & $* * * *(+)$ & $* * * / * * * *(+)$ & & $* * * *(+)$ & & $P$ & $* * *$ & $* * *$ & $* * *$ \\
\hline $\mathrm{PPQ}$ & $\begin{array}{l}\text { Local quality } \\
\text { improvement }\end{array}$ & $* * * *(+)$ & $* * * *(+)$ & & $* * * *(+)$ & & $P$ & $* *$ & $* * * *$ & $* * *$ \\
\hline
\end{tabular}

Ratings of study quality: *poor, ${ }^{* *}$ fair, ${ }^{* * *}$ good, ${ }^{* * * *}$ excellent. Ratings of measurement results: $(+)$ positive rating, $(-)$ negative rating, (?) indeterminate rating, $(\stackrel{+}{)})$ mixed. Correct source of error: $Y$ yes, $\mathrm{N}$ no, $\mathrm{P}$ partial

which the data will be used, available resource and local context. For example, where an instrument is to be used for high stakes purposes (perhaps attached to a financial incentive, public league tables or an outcome measure in a research study), an instrument with high reliability should be selected, such as HCAHPS. However, high costs in terms of resource would need to be accepted as HCAHPS requires compliance with standardised sampling, data collection and statistical expertise to analyse the data. Alternatively, if an instrument is to be used to measure the effectiveness of local quality improvement work, then QPPS may be the instrument of choice, as it rated good for user acceptability and cost efficiency. Similarly, but in a low-income setting, I-PAHC could be a useful instrument as it has scored 'good' and 'excellent' in all dimensions of instrument utility. Also, brief instruments, such as QPPS or PPE-15, may be used as screening instruments to determine a sample for more detailed exploration.

Context is also important, particularly in relation to theoretical development and content validity. For example, if work has been carried out to determine what quality of hospital care means to a local population, as with SIPES in Scotland, then this would be the instrument of choice in Scotland in terms of its content validity. Where instruments are utilised in other countries, studies of cross-cultural validity should be conducted before instrument use.

As with all literature reviews, our findings are dependent upon the quality of detail available in the published literature. There are risks that unpublished instruments have been missed. While our literature search did not include the EMBASE database for pragmatic reasons, we did conduct a thorough search of MEDLINE, 
CINHAL and PsychINFO, as well as specialist databases in the field of patient experience. We also acknowledge that only $10 \%$ of the inclusion criteria was independently checked by two reviewers. Despite checking secondary references, we found no other instruments meeting our inclusion criteria.

Also, there is a possibility that included instruments have been harshly critiqued. We used the COSMIN criteria which reduces scores for methodological quality when insufficient information is available and applies the 'lowest score counts' for an overall score [3]. Some psychometric studies may have only been rated as poor or fair on one item response, subsequently giving a low overall rating. However, a design strength of the COSMIN four-point rating scale was to ensure that only fatal flaws are categorised as poor. Therefore, some item responses cannot be categorised as poor. For example, some checklists determine whether or not the percentage of missing items was reported. Responses are either 'yes' or 'no'. A response of 'no' could still achieve a 'good' quality rating as this question did not offer a 'poor' response option. While having missing items is not regarded as good practice, COSMIN developers determine that the overall quality of the study could still be good or excellent [51]. We limited bias by making reasonable attempts to contact instrument developers for further information and complete scoring independently before arriving at definitive results.

Using the criteria from Terwee et al [50] for results of measurement properties offered a rigorous, equitable and transparent critique of study results. Some instruments may have just fallen below the criteria set and therefore been rated as a negative. That is not to say the instrument cannot be used; rather, some caution should be applied when considering instrument selection. Depending on the purpose of the instrument, lower levels of reliability may have been acceptable; however, the cut-off point needed to be set somewhere.

There were also some psychometric results which did not fit the Quality Criteria for Measurement Properties' results [50], such as studies which used structural equation modelling, which were subsequently categorised as indeterminate. Applying the quality criteria was extremely time-consuming; for example, some studies took several hours. Some criteria required to be more explicit; for example, the criteria for structural validity required factors to explain more than $50 \%$ of variance. It was unclear whether $50 \%$ was required for each factor or total factors. We used total factors and reached decisions on anomalies through consensus discussion.

We do not suggest that the additional dimensions of utility are definitive; rather, this paper offers a starting point of a method to critique these additional, but fundamental, aspects of instrument use. Although offering a degree of face validity, further work is required to determine application to instruments measuring other constructs. A working manual would also provide explanatory guidance for other users. As well as instrument selection, the matrix can also be used to identify research gaps for existing instruments, for example, further validity testing for the SIPES instrument or reliability studies for NHSIP. Instrument development should start with a sound theoretical development of what constitutes Quality from the Patients' Perspective. New instruments may be necessary if there are revised theoretical and conceptual developments of what constitutes quality of hospital care. Advances in how to quantify patient experience may also necessitate the development of new instruments.

\section{Conclusions}

Patient experience data could be used to drive improvements in hospital care at national, local and healthcare team levels. To date, there are a range of instruments available to measure the patient experience of hospital quality care. Clinicians, managers, policy makers and researchers need to select patient experience instruments which are fit for purpose. This study aims to aid this choice by providing a framework to allow consideration of a wide perspective of the utility of instruments. Users can weigh the importance of each dimension, depending on the purpose of data collection, thus aiding instrument choice. Selecting the right patient experience instrument for the right purpose can aid improvements in hospital quality of care.

\section{Additional files}

Additional file 1: PRISMA (2009) Checklist. This file contains a checklist of the criteria necessary for reporting a systematic review, detailing where specific criteria are covered in the paper.

Additional file 2: Search results. This file contains the search strategy conducted in MEDLINE and results of all database and grey literature searching.

\section{Abbreviations}

CINAHL: Cumulative Index to Nursing and Allied Health Literature COSMIN: Consensus-based Standards for the Selection of Health Measurement Instruments; HCAHPS: Hospital Consumer Assessment of Healthcare Providers and Systems; HKIEQ: Hong Kong Inpatient Experience Questionnaire; I-PAHC: Patient Experiences with Inpatient Care; MEDLINE: Medical Literature Analysis and Retrieval System Online; NHSIP: National Health Service Inpatient Survey; NORPEQ: Norwegian Patient Experience Questionnaire; PEQ: Patient Experience Questionnaire; PPE-

15: Picker Patient Experience Questionnaire; PPQ: Patient Perceptions of Quality; PsychINFO: Psychological Information; QPP: Quality from the Patients' Perspective; QPPS: Quality from the Patients' Perspective Shortened; SIPES: Scottish Inpatient Patient Experience Survey.

\section{Competing interests}

The authors declare that they have no competing interests. 


\section{Authors' contributions}

MB conceived and designed the study, devised search strategies, applied inclusion criteria, applied quality scoring, developed the matrix and drafted the manuscript. DM provided direction for the study idea and design, provided statistical advice, applied quality scoring and helped devise matrix and the manuscript. IA participated in the study design, piloting of inclusion selection form and revision of the manuscript. WL participated in the study design, provided statistical advice, applied inclusion criteria, applied quality scoring and revision of the manuscript. All authors have read and approved the final manuscript.

\section{Acknowledgements}

Many thanks to Rob Polson, Subject Librarian, who assisted with database searching and Ref Works support. Thanks to instrument developers and study authors who responded and provided information via e-mail queries and telephone discussions.

\section{Funding}

No specific funding has been granted for the study; however, the University of Stirling is funding fees for a PhD by publication by the first author. It is proposed that this paper will constitute part of the PhD by publication submission.

\section{Author details}

${ }^{1}$ School of Health Sciences, Centre for Health Science, University of Stirling, Highland Campus, Old Perth Rd, Inverness IV2 3JH, UK. ${ }^{2}$ Quality, Safety and Informatics Research Group, University of Dundee, Dundee, UK. ${ }^{3}$ School of Nursing, Midwifery and Social Care, Edinburgh Napier University, Edinburgh, UK. ${ }^{4}$ School of Health Sciences, University of Stirling, Stirling, UK.

\section{Received: 13 March 2015 Accepted: 8 July 2015}

\section{Published online: 23 July 2015}

\section{References}

1. Agency for Healthcare Research and Quality. HCAHPS Fact Sheet CAHPS Hospital Survey. USA; 2012

2. Agency for Healthcare Research and Quality. HCAHPS Survey 2012. [http:// www.hcahpsonline.org/Files/HCAHPS\%20V7\%200\%20Appendix\%20A1\%20\%20HCAHPS\%20Expanded\%20Mail\%20Survey\%20Materials\%20(English)\%20 July\%202012.pdf].

3. Bannignan K, Watson R. Reliability and validity in a nutshell. Jn Clin Nurs 2009:18:3237-43.

4. Beattie M, Lauder W, Atherton I, Murphy D. Instruments to measure patient experience of health care quality in hospitals: a systematic review protocol. Syst Rev. 2014;3:4.

5. Beattie M, Shepherd A, Howieson B. Do the Institute of Medicines' (IOM) dimensions of quality capture the current meaning of quality in health care? -an integrative review. J Res Nurs. 2012;18:288-304.

6. Boyd J. The 2006 inpatients importance study. Oxford, Picker Institute Europe: The Acute Co-ordination Centre for the NHS Acute Patient Survey Programme; 2007

7. Castle NG, Brown J, Hepner K, Hays R. Review of the literature on survey instruments used to collect data on hospital patients' perceptions of care. Health Serv Res. 2005;40:1996-2017.

8. Centers for Medicare and Medicaid (CMS). CAHPS Hospital Survey (HCAHPS) quality assurance guidelines. Baltimore: CMS; 2013.

9. Cleary P, Edgman-Levitan S, Robert M. Patient evaluate their hospital care: a national survey. Health Aff. 1991;10:254-67.

10. Coaley K. An introduction to psychological assessment and psychometrics. London: Sage publications; 2014.

11. Coulter A, Fitzpatrick R, Cornwell J. The point of care measures of patients' experience in hospital: purpose, methods and uses. The Kings fund. 2009. p. 1-32

12. Council of Medical Speciality Societies. The measurement of health care performance: a primer from the CMSS. USA: United Health Services Inc; 2007.

13. DeCourcy A, West E, Barron D. The National Adult Inpatient Survey conducted in the English National Health Service from 2002 to 2009: how have the data been used and what do we know as a result? BMC Health Serv Res. 2012:12:71.

14. Department of Health. Patients first and foremost: the initial government response to the report of the Mid Staffordshire NHS Foundation Trust Public Inquiry. London: Stationary Office; 2013.
15. DeVet H, Terwee C, Mokkink L, Knol D. Measurement in medicine. New York: Cambridge University Press; 2011.

16. Donabedian A. Explorations in quality assessment and monitoring, Vol. 1 , The definition of quality and approaches to its assessment. Ann Arbour: Health Admin Press; 1980.

17. Foundation H. Measuring patient experience: No. 18, evidence scan. Health Foundation: England; 2013

18. Francis R. Report of the Mid Staffordshire NHS Foundation Trust Public Inquiry. London: Stationary Office; 2013.

19. Gerteis M, Edgman-Levitan S, Delbanco T. Through the patient's eyes. Theoretical development of what defines quality from the patients' perspective. San Francisco: Jossey-Bass; 1993

20. Giordano L, Ellito M, Goldstein E, Lehrman E, Spencer P. Development, implementation and public reporting of the HCAHPS Survey. Med Care Res Rev. 2009;67:27-37.

21. Groene O, Botje D, Sunol R, Andree-Lopez M, Wagner C. A systematic review of instruments that assess the implementation of hospital quality management systems. Int J Qual Health Care. 2013;25:525-41.

22. Hospital Authority. Patient satisfaction survey in Hong Kong Hospital Authority; Final Report. Hong Kong; 2010

23. Institute of Medicine (IOM). Crossing the quality chasm: a new health system for 21st century. Washington DC: National Academy Press; 2001

24. Jenkinson C, Coulter A, Reeves R, Bruster S, Richards N. Properties of the Picker Patient Experience questionnaire in a randomized controlled trial of long versus short form survey instruments. J Public Health Med. 2003;25:197-201.

25. Jenkinson C, Coulter A, Bruster S. The Picker Patient Experience Questionnaire: development and validation using data from in-patient surveys in five countries Int J Qual Health C. 2002:14:353-8.

26. Keller S, O'Malley A, Hays RD, Mathew RA, Zaslavsky AM, Hepner AM, et al. Methods used to streamline the CAHPS Hospital Survey. Health Serv Res. 2005:40:2057-77.

27. Larsson BW, Larsson G. Development of a short form of the Quality from the Patient's Perspective (QPP) questionnaire. J Clin Nurs. 2002;11:681-7.

28. Larsson G, Larsson BW, Munck IME. Refinement of the questionnaire 'quality of care from the patient's perspective' using structural equation modelling. Scand J Caring Sci. 1998;12:111-8.

29. Levine RE, Fowler FJ, Brown JA. Role of cognitive testing in the development of the CAHPS Hospital Survey. Health Serv Res. 2005;40:2037-56.

30. Locock L, Robert G, Boaz A, Vougioukalou S, Shuldham C, Fielden J, et al Using a national archive of patient experience narratives to promote local patient-based co-design. J Health Serv Res Policy. 2014;4:200-7.

31. Luxford K. What does the patient know about quality? Int In Qual Health Care. 2012:24:439-40.

32. Manary MP, Boulding W, Staelin R, Glickman SW. The patient experience and health outcomes. N Engl J Med. 2013;368:201-3.

33. Moher D, Liberati A, Tetzlaff J, Altman DG. Preferred reporting items for systematic reviews and meta-analyses: the PRISMA statement. J Clin Epidemiol. 2009;62:1006-12.

34. Mokkink L, Terwee C, Patrick D, Alonso J, Stratford P, Knol D, et al. The COSMIN checklist for assessing the methodological quality of studies on measurement properties of health status measurement instruments: an international Delphi study. Qual Life Res. 2010:19:539-49.

35. Murphy DJ, Bruce DA, Mercer SW, Eva KW. The reliability of workplace-based assessment in postgraduate medical education and training: a national evaluation in general practice in the United Kingdom. Adv Health Sci Edu. 2009:14:219-32

36. O'Malley AJ, Zaslavsky AM, Hays RD, Hepner KA, Keller S, Cleary PD Exploratory factor analyses of the CAHPS Hospital Pilot Survey responses across and within medical, surgical and obstetric services. Health Serv Res. 2005:40:2078-94

37. Oltedal S, Garrat A, Bjertnaes O, Bjornsdottir M, Freil M, Sachs M. The NORPEQ patient experience questionnaire: data quality, internal consistency and validity following a Norwegian inpatient survey. Scand J Caring Sci. 2007;35:540-7.

38. Osse B, Vernooij-Dassen M, Schade E, Grol R. A practical instrument to explore patients' needs in palliative care: the problems and needs in palliative care. Palliative Med. 2007;21:391-9.

39. Pettersen KL, Veenstra M, Guldvog B, Kolstad A. The Patient Experiences Questionnaire: development. Int J Qual Health C. 2004;16:453-63. 
40. Picker Institute Europe. Guidance manual for the NHS Adult Inpatient Survey 2012. Oxford: Picker Institute Europe; 2012.

41. Rao KD, Peters DH, Bandeen-Roche K. Towards patient-centered health services in India—a scale to measure patient perceptions of quality. Int J Qual Health C. 2006;18:414-21.

42. Reeves R, Coulter A, Jenkinson C, Cartwright J, Bruster S, Richard N. Development and pilot testing of instruments for use in the acute NHS Trust Inpatient Survey Programme. Oxford: Picker Institute; 2002.

43. Scales Jr C, Schulman K. Triggering management for quality improvement. Health Serv Res. 2014;49(5):1401-6.

44. Schroder A, Larsson B, Ahlstrom G. Psychometric properties of the instrument quality in psychiatric care and descriptions of quality of care among in-patients. IJHCQA. 2010:23:554-70.

45. Scottish Government. Scottish Inpatient Patient Experience Survey 2010, Volume 2: Technical Report. (http://www.scotland.gov.uk/Publications/2010/ 09/30111425/0).

46. Scottish Government. Scottish Inpatient Patient Experience Survey 2012, Volume 2: Technical Report. (http://www.scotland.gov.uk/Publications/2012/ 08/5616/0).

47. Sizmur S, Redding D. Core domains for measuring inpatients' experience of care. Oxford: Picker Institute Europe; 2012

48. Sofaer S, Crofton C, Goldstein E, Hoy E, Crabb J. What do consumers want to know about the quality of care in hospitals? Health Serv Res. 2005;40:2018-36

49. Streiner DL, Norman GR. Health measurement scales (3rd ed.). Oxford: Oxford Medical Publications; 2003.

50. Terwee CB, Bot SD, de Boer M, van der Windt DA, Knol DL, Dekker J, et al. Quality criteria were proposed for measurement properties of health status instruments. J Clin Epidemiol. 2007;60:34-42.

51. Terwee CB, Mokkink LB, Knol DL, Ostelo RW, Bouter LM, de Vet HCW. Rating the methodological quality in systematic reviews of studies on measurement properties: a scoring system for the COSMIN checklist. Qual Life Res. 2012:21:651-7.

52. Van der Vleuten C. The assessment of professional competence: developments, research and practical implications. Adv in Health Sci Educ. 1996;1:41-67.

53. Webster TR, Mantopoulos J, Jackson E, Cole-Lewis H, Kidane L, Kebede A et al. A brief questionnaire for assessing patient healthcare experiences in low-income settings. Int J Qual Health C. 2011;23:258-68.

54. Wensing M, Elwyn G. Research in patients' views in the evaluation and improvement of quality of care. Qual Saf Health Care. 2002;11:153-7.

55. Wilde B, Larsson G, Larsson M, Starrin B. Quality of care: development of a patient-centred questionnaire based on a grounded theory model. Scand J Caring Sci. 1994:8:39-48

56. Wilde B, Starrin B, Larsson G, Larsson M. Quality of care from a patient perspective: a grounded theory study. Scand J Caring Sci. 1993:7:113-20.

57. Williams B. Patient satisfaction: a valid concept? Soc Sci Med. 1994;38:509-16.

58. Williams B, Coyle J, Healy D. The meaning of patient satisfaction: an explanation of high reported levels. Soc Sci Med. 1998;47:1351-9.

59. Wong EL, Coulter A, Cheung AW, Yam CH, Yeoh EK, Griffiths SM. Validation of inpatient experience questionnaire. Int J Qual Health C. 2013;25:443-51.

\section{Submit your next manuscript to BioMed Central and take full advantage of:}

- Convenient online submission

- Thorough peer review

- No space constraints or color figure charges

- Immediate publication on acceptance

- Inclusion in PubMed, CAS, Scopus and Google Scholar

- Research which is freely available for redistribution 